\title{
PENGARUH GAJI DAN INSENTIF KARYAWAN TERHADAP PRESTASI KERJA KARYAWAN PADA GEDUNG WANITA RAJAWALI PALEMBANG
}

\author{
Eni Cahyani \\ Dosen Politeknik
}

\begin{abstract}
ABSTRAK
Penelitian ini menguji Untuk mengetahui pengaruh gaji dan insentif terhadap prestasi kerja karyawan pada gedung wanita rajawali Palembang. Metode penelitian ini menggunakan

metode deskriptif adalah metode analisa yang tidak hanya mengambarkan tetapi juga menguraikan dan mengambil kesimpulan yang tidak terlalu jauh dari data yang diperoleh.

Hasil analisis dan pembahasan menunjukkan. ada pengaruh yang positif dan signifikan antara gaji dan insentif terhadap prestasi kerja karyawan. Dengan demikian hipotesisnya terbukti dan dari hasil persamaan regresi linier berganda dengan nilai koefisien 0,072 dan 0,111 menunjukkan bahwa Gaji dan Insentif berpengaruh positif dengan Prestasi Kerja Karyawan. Dimana semakin baik pelaksanaan Gaji dan Insentif Karyawan maka akan mempengaruhi prestasi kerja karyawan dan dapat maeningkatkan prestasi kerja karyawan
\end{abstract}

\section{Kata Kunci: Gaji, Insentif dan Prestasi kerja karyawan}

\section{PENDAHULUAN}

\subsection{Latar Belakang Masalah}

Perusahaan pada umumnya didirikan dengan tujuan dapat melangsungkan hidupnya dan diharapkan dapat memperoleh laba yang maksimum. Untuk itu perusahaan harus memperhatikan ketatnya persaingan dalam dunia bisnis dan kondisi perekonomian yang tidak menguntungkan,memaksa para pengusaha untuk selalu giat berusaha agar perusahaan mampu menghasilkan laba yang maksimal. Untuk mencapai laba yang maksimal, setiap perusahaan dalam melakukan kegiatannya tidak terlepas dari peran sumber daya-sumber daya yang ada pada perusahaan tersebut, salah satunya adalah manusia. Sumber daya manusia merupakan faktor utama bagi kelancaran dan kelangsungan hidup sebuah perusahaan.

Gedung Wanita Rajawali merupakan gedung yang di kelola dan disewakan oleh ussaha perseorangan . Pengelolaan bisa digunakan ceremony yang dilengkapi dengan wedding, catering, dan perlengkapan pelaminan, baju pengantin, mobil pengantin, taman dekor pelaminan, organ, penyanyi dan penari. Gedung wanita rajawali ini dikelola secara perorangan oleh Bapak Robert Yudha Titaley dengan jumlah karyawan sebanyak 32 orang. Untuk menumbuhkan dan meningkatkan motivasi para karyawan,maka seorang manajer harus mampu meningkatkan produktivitas karyawannya agar lebih bersemangat dan giat dalam melaksanakan pekerjaan. Adapun yang dapat membangkitkan motivasi kerja karyawan diantaranya adalah pemberian upah atau gaji yang sesuai. Maksud dari gaji dan insentif dalam penelitian ini adalah suatu penerimaan sebagai suatu imbalan dari pemberi kerja kepada penerima kerja untuk suatu pekerjaan atau jasa yang telah dan akan dilakukan, yang berguna sebagai jaminan kelangsungan kehidupan yang layak bagi kemanusiaan dan produksi dinyatakan atau dinilai dalam bentuk uang yang ditetapkan menurut suatu persetujuan, Undang-undang dan peraturan dan dibayarkan atas dasar suatu perjanjian kerja antara pemberi kerja dan penerima kerja. Sedangkan faktor lain yang juga dimungkinkan berpengaruh terhadap peninkatan prestasi kerja adalah gaji dan insentif. Adanya Gaji dan insentif ini dapat meningkatkan prestasi kerja karyawan. Dengan demikian gaji dan insentif sangat penting dan perlu mendapat perhatian, karena hal ini sangat berpengaruh erat dengan prestasi kerja karyawan suatu perusahaan.

Prestasi kerja karyawan merupakan masalah yang sangat penting karena prestasi kerja dapat menjadi indikator kemajuan suatu perusahaan. Prestasi kerja dapat didefinisikan hasil kerja (output) baik kualitas maupun kuantitas yang dicapai SDM persatuan periode waktu dalam melaksanakan tugas kerjanya 
sesuai dengan tanggung jawab yang diberikan kepadanya (Mangkunegara 2009:9).

Hal ini dipengaruhi oleh masa kerja dan posisi karyawan tersebut Mengingat pentingnya pengaruh faktor gaji dan intensif dalam peningkatan prestasi kerja karyawan guna mencapai tujuan perusahaan,maka dalam penyusunan skripsi ini penulis mengambil judul: "PENGARUH GAJI DAN INSENTIF KARYAWAN TERHADAP PRESTASI KERJA KARYAWAN PADA GEDUNG WANITA RAJAWALI PALEMBANG"

\subsection{Tujuan Penelitian}

Tujuan dilaksanakan penelitian di gedung wanita rajawali Palembang antara lain:

1. Untuk mengetahui pengaruh gaji dan insentif terhadap prestasi kerja karyawan pada gedung wanita rajawali Palembang

2. Untuk mengetahui faktor mana yang paling dominan mempengaruhi gaji dan insentif terhadap prestasi kerja karyawan pada gedung wanita rajawali Palembang

\section{TINJAUAN PUSTAKA}

\subsection{Pengertian Gaji}

Gaji adalah salah satu hal yang penting bagi setiap karyawan yang bekerja dalam suatu perusahaan, karena dengan gaji yang diperoleh seseorang dapat memenuhi kebutuhan hidupnya. Hasibuan (2002) menyatakan bahwa "Gaji adalah balas jasa yang dibayar secara periodik kepada karyawan tetap serta mempunyai jaminan yang pasti" ( $p$. 118). Pendapat lain dikemukakan oleh Handoko (1993), "Gaji adalah pemberian pembayaran finansial kepada karyawan sebagai balas jasa untuk pekerjaan yang dilaksanakan dan sebagai motivasi pelaksanaan kegiatan di waktu yang akan datang" (p. 218).

Perusahaan yang tergolong modern, saat ini banyak mengaitkan gaji dengan kinerja.

Pernyataan di atas juga didukung oleh pendapat Mathis dan Lackson (2002), "Gaji adalah suatu bentuk kompensasi yang dikaitkan dengan kinerja individu, kelompok ataupun kinerja organisasi” (p. 165).

\subsection{Peranan Gaji}

Menurut Poerwono (2002) peranan gaji dapat ditinjau dari dua pihak, yaitu :

a. Aspek pemberi kerja (majikan) adalah manager, Gaji merupakan unsur pokok dalam menghitung biaya produksi dan komponen dalam menentukan harga pokok yang dapat menentukan kelangsungan hidup perusahaan. Apabila suatu perusahaan memberikan gaji terlalu tinggi maka, akan mengakibatkan harga pokok tinggi pula dan bila gaji yang diberikan terlalu rendah akan mengakibatkan perusahaan kesulitan mencari tenaga kerja.

b. Aspek penerima kerja,Gaji merupakan penghasilan yang diterima oleh seseorang dan digunakan untuk memenuhi kebutuhannya. Gaji bukanlah merupakan satu - satunya motivasi karyawan dalam berprestasi, tetapi gaji merupakan salah satu motivasi penting yang ikut mendorong karyawan untuk berprestasi, sehingga tinggi rendahnya gaji yang diberikan akan mempengaruhi kinerja dan kesetiaan karyawan.

\subsection{Fungsi Penggajian}

Menurut Komaruddin (2005) fungsi gaji bukan hanya membantu manajer personalia dalam menentukan gaji yang adil dan layak saja, tetapi masih ada fungsi-fungsi yang lain, yaitu (p. 164) :

1. Untuk menarik pekerja yang mempunyai kemampuan ke dalam organisasi

2. Untuk mendorong pekerja agar menunjukkan prestasi yang tinggi

3. Untuk memelihara prestasi pekerja selama periode yang panjang

\subsection{Tujuan Penggajian}

Menurut Hasibuan (2002)

tujuan penggajian, antara lain :
a. Ikatan kerja sama
b. Kepuasan kerja
c. Pengadaan efektif
d. Motivasi
e. Stabilitas karyawan
f. Disiplin
g. Pengaruh serikat buruh
h. Pengaruh pemerintah 


\subsection{Pengertian Insentif}

Insentif sebagai sarana motivasi yang mendorong para pegawai untuk bekerja dengan kemampuan yang optimal, yang dimaksudkan sebagai pendapatan ekstra di luar gaji atau upah yang telah ditentukan. Pemberian insentif dimaksudkan agar dapat memenuhi kebutuhan para pegawai dan keluarga mereka. Istilah sistem insentif pada umumnya digunakan untuk menggambarkan rencana-rencana pembayaran upah yang dikaitkan secara langsung atau tidak langsung dengan berbagai standar kinerja pegawai atau profitabilitas organisasi. Insentif dapat dirumuskan sebagai balas jasa yang memadai kepada pegawai yang prestasinya melebihi standar yang telah ditetapkan.Insentif merupakan suatu faktor pendorong bagi pegawai untuk bekerja lebih baik agar kinerja pegawai dapat meningkat. Untuk memperoleh engertian yang lebih jelas tentang insentif, di bawah ini ada beberapa ahli manajemen mengemukakan pengertian mengenai insentif.

Menurut Malayu S.P Hasibuan (2012:117), mengemukakan bahwa: "Insentif adalah tambahan balas jasa yang diberikan kepada karyawan tertentu yang prestasinya di atas prestasi standar. Insentif ini merupakan alat yang dipergunakan pendukung prinsip adil dalampemberian kompensasi". Sementara itu, Siagian (2010:268) juga menjelaskan bahwa "insentif diberikan guna mendorong produktifitas kerja yang lebih tinggi bagi karyawannya".Jadi menurut pendapatpendapat para ahli di atas dapat penulis simpulkan, bahwa insentif adalah dorongan pada seseorang agar mau bekerja dengan baik dan agar dapat mencapai prestasi kerja yang tinggi sehingga dapat membangkitkan gairah kerja dan motivasi seorang pegawai. Di mana pada prinsipnya pemberian insentif menguntungkan kedua belah pihak. Perusahaan mengharapkan adanya kekuatan atau semangat yang timbul dalam diri penerima nsentif yang mendorong mereka untuk bekerja dengan lebih baik dalam arti lebih produktif agar tujuan yang ingin dicapai oleh perusahaan dapat terpenuhi sedangkan bagi pegawai sebagai salah satu alat pemuas kebutuhannya.

\subsection{Tujuan Pemberian Insentif}

Menurut Panggabean (2010 : 89)

tujuan insentif adalah untuk memberikan tanggung jawab dan dorongan kepada karyawan. Selanjutnya Ranupandojo dan Suad Husnan (2010 : 162) dalam bukunya Manajemen Personalia bahwa tujuan pemberian insentif adalah :

a. Mempertahankan karyawan yang berprestasi untuk tetap dalam perusahaan,

b. Memberikan kegairahan untuk menaikkan produktifitas,

c. Memberikan perangsang dalam usaha mencapai kedisiplinan kerja karyawan yang utuh,

d. Untuk meningkatkan OutPut,

e. Menambah penghasilan dari pada karyawan.

Dalam suatu perusahaan setiap karyawan dalam melakukan suatu kegiatan mempunyai maksud dan tujuan yang berbedabeda. Perbedaan tersebut disebabkan karena kebutuhan manusia bermacam-macam dan selalu merasa tidak puas dalam keadaannya sekarang. Untuk memenuhi kebutuhan sehariharinya maka diperlukan penghasilan tambahan bagi karyawan. Sehingga hal tersebut perlu diperhatikan oleh pimpinan sebuah perusahaan.

Tujuan utama dari pemberian insentif ini sebenarnya untuk merangsang atau memberikan dorongan kepada karyawan supaya mau melaksanakan pekerjaannya melebihi standart yang telah ada atau melebihi kemampuan rata-rata. Karena tujuan perusahaan merupakan suatu hal yang penting bagi perusahaan maka perusahaan akan melakukan berbagai cara untuk mencapai tujuan yang telah direncanakan tersebut.

\subsection{Jenis - jenis Insentif}

Menurut pendapat Hasibuan (2012: 195) ada dua macam bentuk insentif yaitu "insentif material" (material insentif)dan "insentif non material" (non material insentif)

. a. Material Insentif adalah material sebuah imbalan prestasi yang diberikan, yang termasuk dalam material insentif adalah upah, barang-barang dan yang sejenisnya,

b. Non Material Insentif adalah motivasi yang tidak berbentuk materi, yang termasuk non material insentif adalah penempatan yang tepat, latihan yang sistematis, promosi yang obyektif, pekerjaan yang terjamin, program penghargaan, bintang jasa, perlakuan yang wajar dan yang sejenisnya. 
Selain pendapat diatas, untuk memotivasi karyawan agar lebih berprestasi Manullang (2009:150) menjelaskan insentif dapat dikelompokkan menjadi 3 golongan dan dapat disarikan sebagai berikut :

a. Material Incentive adalah Segala daya perangsang yang dapat dinilai dengan uang,

b. Semi Material Insentive adalah Semua jenis perangsang yang tidak dapat dinilai dengan uang, meliputi: penempatan yang tepat, latihan sistematik, promosi yang obyektif, pekerjaan yang terjamin, turut sertanya wakil-wakil pegawai dalam menggambil keputusan perusahaan, kondisi-kondisi pekerjaan yang menyenangkan, pemberian informasi tentang : perusahaan, fasilitas- fasilitas tenteng rekreasi, penjagaan kesehatan perusahaan dan sebagainya.

c. Non Material Insentive pada hakekatnya adalah sikap pimpinan terhadap bawahannya, pegawai harus mempunyai kepercayaan terhadap atasannya. Sikap pimpinan akan memberikan kegairahan bekerja kepada pegawai seperti mempunyai sifat kejujuran dan tidak mementingkan diri sendiri.

\subsection{Pengertian Prestasi Kerja Karyawan}

Prestasi kerja merupakan istilah yang berasal dari kata job performance atau actual performance (prestasi kerja atau prestasi sesungguhnya yang dicapai seseorang). Prestasi kerja adalah hasil kerja (output) baik kualitas maupun kuantitas yang dicapai SDM persatuan periode waktu dalam melaksanakan tugas kerjanya sesuai dengan tanggung jawab yang diberikan kepadanya (Mangkunegara 2009:9).

Prestasi merupakan salah satu kebutuhan manusia yang terpenting dan selalu ingin dicapai. Prestasi kerja merupakan keadaan dimana seseorang merasa bahwa dia telah dapat menyelesaikan pekerjaanya dan merasa hasil pekerjaannya itu merupakan kebutuhan orang lain (pekerjaan itu berharga). Pengertian prestasi kerja pada dasarnya adalah kegiatan dan hasil yang dapat dicapai atau ditunjukkan seseorang maupun sekelompok orang didalam pelaksanaan tugas pekerjaan dengan baik. Artinya mencapai sasaran atau standar kerja yang telah ditetapkan sebelum dan atau bahkan dapat melebihi standar yang telah ditentukan oleh perusahaan pada periode tertentu.

\subsection{Faktor-Faktor Yang Mempengaruhi Prestasi Kerja}

Adapun beberapa faktor yang mempengaruhi tinggi rendahnya prestasi kerja yaitu

1) Hubungan yang harmonis antara pimpinan dan bawahan terutama antar pimpinan kerja yang sehari-hari langsung berhubungan dengan para pekerja bawahan.

2) Kepuasan para pekerja terhadap Tugas dan pekerjaannya karena memperoleh tugas yang disukai sepenuhnya.

3) Terdapatnya suatu rencana dan iklim kerja yang bersahabat dengan anggota-anggota lainnya, organisasi apabila dengan mereka yang sehari-hari banyak berhubungan dengan pekerjaanya.

4) Rasa kemanfaatan bagi tercapainya tujuan organisasi yang juga merupakan tujuan bersama yang harus diwujudkan secara bersama-sama pula.

5) Adanya tingkat kepuasan ekonomi dan kepuasan-kepuasan internal lainnya yang memadai sebagai imbalan yang dirasakan adil terhadap jerih payah yang telah diberikan kepada organisasi.

6) Adanya ketenangan jiwa, kepastian serta perlindungan terhadap segala sesuatu yang dapat membahagiakan diri pribadi dan karier dalam pekerjaan.

Seseorang mempunyai prestasi kerja yang baik akan mendapatkan penghargaan yang lebih tinggi. Bila penghargaan itu dirasakan ada dan memadai maka kepuasan kerja karyawan akan meningkat karena mereka menerima penghargaan dalam posisi yang sesuai dengan prestasi kerja mereka. Di lain pihak bila penghargaan dipandang tidak mencukupi untuk suatu tingkat prestasi kerja mereka, ketidakpusan kerja tersebut selanjutnya menjadi umpan balik yang akan mempengaruhi prestasi kerja yangakan datang. Bagaimanapun juga kepuasan kerjaperlu untuk memelihara karyawan agar lebih tanggap terhadap lingkungan motivasi yang diciptakan.

\subsection{Kerangka fikir}

Konsep Kerangka pemikiran adalah istilah dan defenisi yang digunakan untuk menggambarkan secara abstrak mengenai kejadian, keadaan, kelompok atau individu yang menjadi perhatian ilmu sosial. Menurut 
Singarimbun (2010 : 33), konsep adalah abstraksi mengenai suatu fenomena yang dirumuskan atas dasar generalisasi. Untuk mendapatkan batasan-batasan yang lebih jelas mengenai variabel-variabel yang akan diteliti, maka defenisi konsep yang digunakan dalam pengertian ini adalah

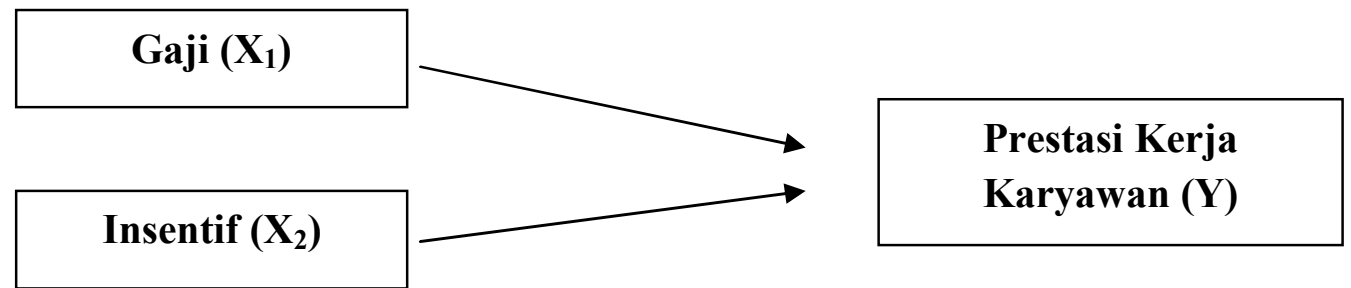

Gambar-1

Desain penelitian ini menjelaskan hubungan antara variabel $(\mathrm{X})$ dengan variabel $(\mathrm{Y})$, dimana Gaji $\left(\mathrm{X}_{1}\right)$ dan Insentif $\left(\mathrm{X}_{2}\right)$ sebagai variabel bebas $(\mathrm{X})$ sangat berpengaruh terhadap Prestasi Kerja Karyawan sebagai variabel terikat $(\mathrm{Y})$.

\subsection{Hipotesis}

Berkaitan dengan permasalahan pokok yang dihadapi perusahaan, maka jawaban atau dugaan sementara atas permasalahan tersebut adalah :

" Ada Pengaruh Faktor Gaji dan Insentif Secara Simultan dan Partial Terhadap Prestasi Kerja Karyawan Pada Gedung Wanita Rajawali Palembang ”

\section{METODE PENELITIAN}

\subsection{Lokasi Penelitian}

- Penelitian ini dilakukan Pada Gedung Wanita Jalan Rajawali Lrg. KakaK Tua No.31 Palembang

\subsection{Populasi dan Sampel \\ 3.2.1 Populasi}

Menurut Sugiyono

Populasi merupakan wilayah generalisasi yang terdiri dari atas objek atau subjek mempunyai kualitas dan karekteristik tertentu Dalam penelitian ini Semua karyawan gedung rajawali palaembang adalah populasi dimana jumlah seluruhnya 32 orang.

\subsubsection{Sampel}

Menurut Sugiyono (2007:64) Sampel adalah Sampel adalah sebagian dari anggota populasi yang diambil untuk diteliti dan juga dianggap mewakili keseluruhan (Gujarati, 2007). Yang menjadi sampel adalah karyawan gedung wanita rajawali di kota Palembang berjumlah 32 orang

\subsection{Data yang digunakan}

Data penelitian adalah data primer yang dikumpulkan dengan menggunakan kuisioner. Bersama kuisioner dilampirkan surat yang menjelaskan maksud dan tujuan pengisian kuisioner dan waktu pengembalian kuisioner yang telah diisi oleh responden. Teknik penyerahan kuesioner diantar langsung ke perusahaan, dimana teknik ini lebih baik dibandingkan dengan melalui pengiriman kuisioener lewat pos karena dapat memperkecil perbedaan interprestasi antara responden dengan peneliti.

\subsection{Metode Pengumpulan Data}

Dalam penyusunan skripsi ini, penulis mempergunakan metode pengumpulan data sebagai berikut :

a. Studi Kepustakaan

Disini penulis mendapatkan data atau keterangan dengan cara membaca literaturliteratur, tulisan ilmiah, media massa, laporan-laporan maupun publikasi lainnya yang menjadi pedoman dalam penulisan ini

b. Studi Lapangan

Penelitian yang dilakukan oleh penulis secara langsung ke perusahaan yang menjadi objek penelitian dalam penulisan skripsi ini. Dalam studi lapangan ini guna memperoleh data dan informasi yang relevan dengan permasalahan proposal skripsi ini, dengan cara :

Wawancara, yaitu dengan cara melakukan tatap muka secara langsung pada pimpinan Gedung wanita rajawali Palembang : 
1) wewenang untuk memberikan informasi dan data yang relevan dengan masalah dalam penulisan skripsi ini.

2) Obeservasi, yaitu dengan cara mengamati secara langsung kejadiankejadian yang terjadi baik dalam proses produksi maupun kegiatan yang berhubungan dengan peningkatan produktivitas kerja karyawan

\subsection{Metode Analisis Data}

Metode analisis yang penulis gunakan dalam skripsi ini adalah metode deskriptif adalah metode analisa yang tidak hanya mengambarkan tetapi juga menguraikan dan mengambil kesimpulan yang tidak terlalu jauh dari data yang diperoleh.

\subsection{Teknik Analisis Data}

a. Uji Validitas dan Reabilitas

Pada setiap pengukuran selalu diharapkan diperoleh hasil ukur yang akurat dan objektif. Salah satu upaya untuk mencapainya adalah alat ukur yang digunakan harus valid atau sahih dan reliabel atau andal (Simamora, Bilson : 2005: 58). Uji validitas digunakan untuk mendapatkan validitas yang tinggi dari instrumen penelitian sehingga bisa memenuhi persyaratan. Sedangkan uji reliabilitas dilakukan guna memperoleh gambaran yang tetap mengenai apa yang diukur. Uji validitas dan reabilitas ini dengan menggunakan koefisien korelasi Pearson Product Moment yang diperoleh melalui analisa data. Item yang memiliki daya beda cukup tinggi akan dihitung reliabilitasnya dengan menggunakan reliabilitas koefisien alpha yang diperoleh melalui analisis data . Item-item dalam skala yang memiliki validitas yang baik dan reliabel akan digunakan untuk mengukur.

\section{b. Metode Regresi Linier Berganda}

Dalam mengetahui hubungan pengaruh antara gaji dan insentif bterhadap prestasi kerja karyawan digunakan teknik analisis regresi berganda, untuk mengetahui besarnya pengaruh secara kuantitatif dari suatu perubahan (variabel $X$ ) terhadap kejadian lainnya (Variabel Y). Analisis regresi menggunakan rumus persamaan regresi berganda seperti yang dikutip dalam sugiono. (2009:277), yaitu :
$\mathbf{Y}=\mathbf{a}+\mathbf{b}_{1} \mathbf{X}_{1}+\mathbf{b}_{2} \mathbf{X}_{2}$

Dimana :

$\mathrm{Y}=$ Variabel dependen, yaitu Prestasi Kerja Karyawan

$\mathrm{X}_{1}=$ Variabel Independen, yaitu Gaji

$\mathrm{X}_{2}=$ Variabel Indenpenden, yaitu Insentif

$\mathrm{A}=$ Konstanta yang merupakan rata-rata nilai $Y$ pada saat nilai $X_{1}$ dan $X_{2}$ sama dengan . nol

$b_{1}=$ Koefisien regresi parsial, mengukur rata-rata nilai $\mathrm{Y}$ untuk tiap perubahan $\mathrm{X}_{1}$ dengan menganggap X2 konstan

$\mathrm{b}_{2}=$ Koefisien regresi parsial mengukur rata-rata nilai $\mathrm{Y}$ untuk tiap perubahan $\mathrm{X}_{2} \quad$ dengan menganggap $\mathrm{X} 1$ konstan

c. Koefisien determinasi (r2), digunakan untuk melihat besarnya pengaruh variable $\mathrm{X}$ terhadap Y

d. Uji Simultan (Uji-F)

Uji-F ini digunakan untuk mengetahui pengaruh bersama-sama variabel bebas terhadap variabel terikat. Dimana Fhitung $>$ Ftabel, maka H1 diterima atau secara bersama-sama variabel bebas dapat menerangkan variabel terikatnya secara serentak. Sebaliknya apabila Fhitung $<$ Ftabel, maka H0 diterima atau secara bersama-sama variabel bebas tidak memiliki pengaruh terhadap variabel terikat.

Untuk mengetahui signifikan atau tidak pengaruh secara bersama-sama variabel bebas terhadap variabel terikat, maka digunakan probability sebesar $5 \%(\alpha=0,05)$.

Jika sig $>\alpha(0,05)$, maka H0 diterima H1 ditolak

Jika sig $<\alpha(0,05)$, maka H0 ditolak H1 diterima

e. Uji Parsial (Uji-t)

Uji ini digunakan untuk mengetahui apakah masing-masing variabel bebasnya secara sendiri-sendiri berpengaruh secara signifikan terhadap variabel berikutnya. Dimana Ttabel $>$ Thitung, H0 diterima. Dan jika Ttabel < Thitung, maka H1 diterima, begitupun jika sig $>\alpha(0,05)$, maka $\mathrm{H} 0$ diterima H1 ditolak dan jika sig $<\alpha(0,05)$, maka $\mathrm{H} 0$ ditolak $\mathrm{H} 1$ diterima.

\section{HASIL PENELITIAN DAN PEMBAHASAN}

\subsection{Distibusi Responden}

Responden dalam penelitian ini adalah karyawan Gedung Wanita Rajawali 
Palembang keseluruhan populasinya berjumlah 32 karyawan. Dari jumlah tersebut sampel yang diambil juga sebesar $\mathbf{3 2}$ karyawan.

\subsection{Hasil Penelitian}

Pada bab ini akan dibahas mengenai pengaruh pemberian gaji dan insentif karyawan terhadap prestasi kerja karyawan pada gedung wanita rajawali palembang. Adapun data yang diambil dari kuesioner diolah menggunakan SPSS (Statistical Product and Service Solution). Keluaran dari data tersebut diharapkan akan memberikan informasi dan akan dilakukan analisis data serta pembahsan pada bab ini. Diharapkan dari analisis dan pembahsan tersebut dapat menjawab permasalahan dalam rumusan masalah.

Sebelum dilakukan pembahasan lebih lanjut mengenai pengaruh gaji dan insentif karyawan terhadap prestasi kerja karyawan pada gedung wanita rajawali palembang, terlebih dahulu akan dilakukan beberapa pengujian, yaitu uji validitas dan uji variabel. Variabel yang akan diuji tersebut adalah variabel bebas (Independent variabel) yaitu Rekrutment dan Seleksi sedangkan variabel terikat (dependent) yaitu prestasi kerja karyawan pada gedung wanita rajawali palembang.

- Profil Responden

Deskripsi profil responden menguraikan atau menggambarkan identitas responden yang dijadikan sebagai sampel penelitian. Dalam pembahasan profil responden ditetapkan 32 responden. Dimana perlu ditambahkan penyebaran kuesioner kepada responden yang menunjukkan bahwa semua responden telah mengembalikan kuesioner dan telah diisi secara lengkap dan benar. Kemudian perlu ditambahkan bahwa dalam deskripsi profil reponden maka yang ditekankan adalah berdasarkan jenis kelamin, umur, tingkat pendidikan terakhir dan berdasarkan lama kerja. Hal ini dapat diuraikan melalui pembahsan berikut ini :

- Deskripsi profil responden berdasarkan jenis kelamin (gender)

Deskripsi profil responden berdasarkan jenis kelamin yaitu menguraikan atau menggambarkan jenis kelamin responden. Hal ini dapat dikelompokkan menjadi 2 kelompok, yaitu laki-laki dan perempuan.

Adapun deskripsi profil responden menurut jenis kelamin dapat disajikan melalui profil responden menurut jenis kelamin dapat disajikan melalui tabel 6 berikut ini :

Tabel -1

Responden berdasarkan jenis kelamin (gender)

\begin{tabular}{|c|c|c|c|}
\hline No. & Jenis Kelamin & Frekwensi (Orang) & $\begin{array}{c}\text { Persentasi } \\
\text { (\%) }\end{array}$ \\
\hline 01 & Laki-Laki & 18 & 93,75 \\
\hline 02 & Perempuan & 14 & 3,125 \\
\hline & Jumlah & $\mathbf{3 2}$ & $\mathbf{1 0 0 \%}$ \\
\hline
\end{tabular}

\section{Sumber: Gedung Rajawali Palembang 2016}

Berdasarkan tabel-1 deskripsi responden menurut jenis kelamin (gender) menunjukkan bahwa mayoritas responden lebih banyak didomonasikan laki-laki jika dibandingkan dengan perempuan.

\section{- Deskripsi profil responden berdasarkan Tingkat Pendidikan}

Tingkat pendidikan terakhir sangat mempengaruhi kemampuan dan tingkat ke percayaan diri seorang karyawan dalam melakukan pekerjaannya. Karyawan dengan pendidikan yang tinggi akan lebih mampu menyelesaikan pekerjaan dengan tingkat kesulitan yang lebih tinggi daripada karyawan dengan tingkat pendidikan yang lebih rendah. Tanggung jawab dari karyawan dengan tingkat pendidikan yang tinggi biasanya juga jauh lebih tinggi karena mereka lebih dipercaya untuk menangani tingkat pekerjaan yang dianggap tidak mampu dikerjakan oleh karyawan yang kurang pengalaman, apalagi yang berpendidikan tidak terlalu tinggi. Data mengenai responden menurut tingkat pendidikan dapat dilihat pada tabel -7 berikut ini 
Tabel -2

Responden berdasarkan tingkat pendidikan

\begin{tabular}{|c|c|c|c|}
\hline No. & Tingkat Pendidikan & Frekwensi (Orang) & $\begin{array}{c}\text { Persentasi } \\
(\mathbf{\%})\end{array}$ \\
\hline 01. & $\mathrm{SMU}$ & 30 & 93,75 \\
\hline 02. & $\mathrm{~S}_{1}$ & 1 & 3,125 \\
\hline 03. & $\mathrm{~S}_{2}$ & 1 & 3,125 \\
\hline & Jumlah & $\mathbf{3 2}$ & $\mathbf{1 0 0 \%}$ \\
\hline
\end{tabular}

\section{Sumber : Gedung Rajawali Palembang}

Dari Data tabel-2 diatas dapat dilihat bahwa tingkat pendidikan sebagian besar karyawan Gedung Wanita Rajawali Palembang menjadi responden dalam penelitian ini adalah SMU berjumlah 30 orang atau $93,75 \%$. , S1 berjumlah 1 orang dengan persentase $3.125 \%$ dan S2 berjumlah 1 orang dengan persentase $3.125 \%$.

- Deskripsi profil responden berdasarkan usia

Usia seorang karyawan sangat menentukan prestasi kerja secara keseluruhan. karyawan dengan usia relatif masih muda akan mempunyai kemampuan fisik yang lebih baik daripada karyawan yang lebih tua. Akan tetapi seorang karyawan yang sudah berusia lebih tua akan mempunyai pengalaman yang tidak dimilikin oleh karyawan yang masih berusia muda. Oleh karena itu akan lebih baik apabila perusahaan menggabungkan atau memadukan karyawan berusia tua dengan usia muda. Data mengenai responden menurut umur dapat dilihat pada tabel -3 berikut ini :

Tabel 3.

Responden berdasarkan usia

\begin{tabular}{|c|c|c|c|}
\hline No. & Tingkat Pendidikan & Frekwensi (Orang) & $\begin{array}{c}\text { Persentasi } \\
\mathbf{( \% )}\end{array}$ \\
\hline 01. & $<20$ Tahun & 2 & 6,25 \\
\hline 02. & $21-30$ Tahun & 5 & 15,625 \\
\hline 03. & $31-40$ Tahun & 15 & 46,875 \\
\hline 04. & 41-50 Tahun & 10 & 31,25 \\
\hline & Jumlah & $\mathbf{3 2}$ & $\mathbf{1 0 0 \%}$ \\
\hline
\end{tabular}

Sumber : Gedung Rajawali Palembang

Dari Tabel-3 dapat dilihat bahwa sebagian besar karyawan gedung wanita rajawali palembang yang menjadi responden dalam penelitian ini adalah berusia sekitar 31-40 tahun yaitu berjumlah 15 orang atau 46,875 $\%$, karyawan yang berusia 21-30 tahun berjumlah 5 orang atau $15,625 \%$, karyawan yang berusia 41-50 tahun berjumlah 10 orang atau $31,25 \%$ yang paling sedikit adalah karyawan yang berusia 20 tahun yang berjumlah 2 orang atau $6,25 \%$.

- Deskripsi profil responden berdasarkan Masa Kerja

Tabel -4

Responden berdasaarkan masa kerja

\begin{tabular}{|c|c|c|c|}
\hline No. & Tingkat Pendidikan & Frekwensi (Orang) & $\begin{array}{c}\text { Persentasi } \\
\mathbf{( \% )}\end{array}$ \\
\hline 01. & $1-5$ Tahun & 5 & 6,25 \\
\hline 02. & 6-10 Tahun & 2 & 15,625 \\
\hline 03. & 11-15 Tahun & 15 & 46,875 \\
\hline 04. & 16-20 Tahun & 10 & 31,25 \\
\hline & Jumlah & $\mathbf{3 2}$ & $\mathbf{1 0 0 \%}$ \\
\hline
\end{tabular}

Sumber : Gedung Rajawali Palembang 
Dari Tabel-4 dapat dilihat bahwa masa kerja antara 1-5 tahun adalah sebagian besar karyawan Gedung Wanita Rajawali Palembang yang menjadi responden dalam penelitian ini adalah 5 orang atau sebesar $6,25 \%$, karyawan yang bekerja antara 6-10 tahun berjumlah 2 orang atau $15,625 \%$ dan 11-15 tahun adalah masing-masing 15 orang atau $46,876 \%$ dan karyawan yang masa kerja berkisar 16-20 tahun sebanyak 10 orang atau $31,25 \%$.

\section{Rekapitulasi Jawaban Responden}

Salah satu upaya yang dilakukan oleh setiap perusahaan dalam memberikan semangat karyawan dalam melakukan pekerjaannya adalah dengan memberikan gaji dan insentif yang sesuai dengan pekerjaan yang mereka hasilkan. Dimana dengan meningkatkan prestasi kerja dihasilkan. maka perlunya setiap perusahaan memperhatikan masalah gaji dan insentif karyawannya karena hal ini sangat mempengaruhi terhadap prestasi kerja karyawan.

Masalah gaji dan insentif adalah salah satu upaya yang dilakukan dalam memperoleh semangat kerja karyawan, sebab dengan adanya gaji dan insentif yang sesuai dengan pekerjaannya maka akan memberikan dampak yang baik bagi pekerjaan karyawannya.

Dalam hubungannya dengan uraian tersebut diatas, akan dapat disajikan persepsi responden mengenai pengaruh Gaji dan insntif karyawan terhadap prestasi kerja karyawan pada gedung wanita rajawali palembang.

Tabel-5

Distribusi Frekuensi Pernyataan Mengenai Gaji dan Insentif Karyawan Terhadap Prestasi Kerja Karyawan

VARIABEL DEPENDEN PENGARUH GAJI DAN INSENTIF KARYAWAN (X)

1. Variabel Gaji $\left(\mathrm{X}_{1}\right)$

\begin{tabular}{|c|c|c|c|c|c|c|}
\hline No & Pernyataan & STS & TS & KS & $\mathbf{S}$ & SS \\
\hline 1 . & $\begin{array}{l}\text { Gaji diberikan sesuai dengan jadwal yang yang } \\
\text { telah disepakati dengan pihak peusahaan }\end{array}$ & & & 5 & 14 & 13 \\
\hline 2. & $\begin{array}{l}\text { Gaji diberikan sesuai dengan jabatan saya saat } \\
\text { ini didalam perusahaan }\end{array}$ & & & 1 & 15 & 16 \\
\hline 3. & $\begin{array}{l}\text { Gaji diberikan sesuai dengan pengorbanan yang } \\
\text { diberikan kepada peusahaan }\end{array}$ & & & & 20 & 12 \\
\hline 4. & $\begin{array}{l}\text { Gaji langsung yang saya terima sesuai dengan } \\
\text { lamanya bekerja }\end{array}$ & & & 3 & 10 & 19 \\
\hline
\end{tabular}

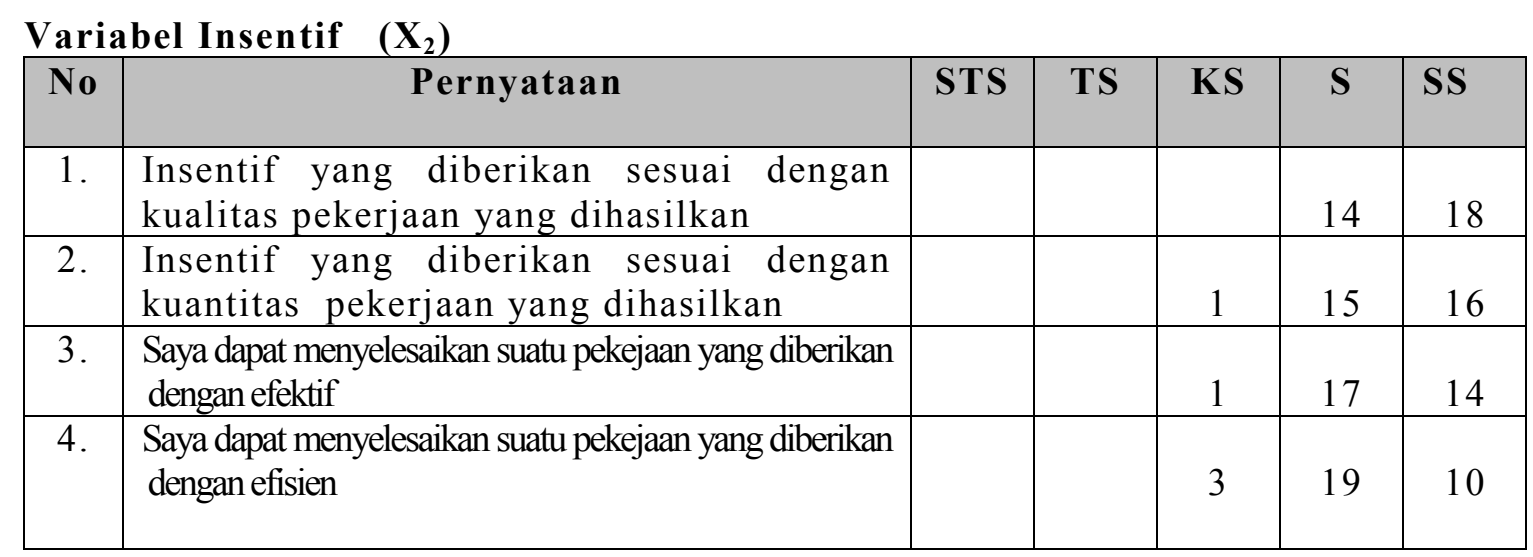


Tabel.-6

Persepsi Jawaban Responden Mengenai Gaji dan Insentif

Karyawan Terhadap Prestasi Kerja Karyawan

\section{Variabel Gaji $\left(\mathrm{X}_{1}\right)$}

1. Gaji diberikan sesuai dengan jadwal yang yang telah disepakati dengan pihak peusahaan

\begin{tabular}{|l|c|c|}
\hline \multirow{2}{*}{\multicolumn{1}{|c|}{ Pernyataan }} & \multicolumn{2}{|c|}{ Gaji } \\
\cline { 2 - 3 } & Frekuensi & \% \\
\hline Sangat Setuju & 13 & 40,625 \\
\hline Setuju & 14 & 43,75 \\
\hline Kurang Setuju & 5 & 15,625 \\
\hline Tidak Setuju & - & - \\
\hline Sangat Tidak Setuju & - & - \\
\hline \multicolumn{1}{|c|}{ Jumlah } & $\mathbf{3 2}$ & $\mathbf{1 0 0 \%}$ \\
\hline
\end{tabular}

Sumber : Gedung Wanita Rajawali Palembang

Dari Tabel-11 dapat dilihat bahwa responden yang menjawab sangat setuju berjumlah 13 orang atau sebesar $40,625 \%$, kemudian responden yang menjawab setuju berjumlah 14 orang atau $43,75 \%$ dan responden yang mengatakan kurang setuju berjumlah 5 orang atau $15,625 \%$.. Jadi responden yang menjawab mayoritas kearah positif.

2. Gaji diberikan sesuai dengan jabatan saya saat ini didalam perusahaan

\begin{tabular}{|l|c|c|}
\hline \multirow{2}{*}{\multicolumn{1}{|c|}{ Pernyataan }} & \multicolumn{2}{c|}{ Gaji } \\
\cline { 2 - 3 } & Frekuensi & \% \\
\hline Sangat Setuju & 16 & 50 \\
\hline Setuju & 15 & 46,875 \\
\hline Kurang Setuju & 1 & 3,125 \\
\hline Tidak Setuju & - & - \\
\hline Sangat Tidak Setuju & - & - \\
\hline \multicolumn{1}{|c|}{ Jumlah } & $\mathbf{3 2}$ & $\mathbf{1 0 0 \%}$ \\
\hline
\end{tabular}

Dari Tabel-11 dapat dilihat bahwa responden yang menjawab sangat setuju berjumlah 16 orang atau sebesar $50 \%$, kemudian responden yang menjawab setuju berjumlah 15 orang atau $46,875 \%$ dan responden yang mengatakan kurang setuju berjumlah 1 orang atau 3,125\%.. Jadi responden yang menjawab mayoritas kearah positif.

3. Gaji diberikan sesuai dengan pengorbanan yang diberikan kepada peusahaan

\begin{tabular}{|l|c|c|}
\hline \multirow{2}{*}{\multicolumn{1}{c|}{ Pernyataan }} & \multicolumn{2}{c|}{ Gaji } \\
\cline { 2 - 3 } & Frekuensi & \% \\
\hline Sangat Setuju & 12 & 37,5 \\
\hline Setuju & 20 & 62,5 \\
\hline Kurang Setuju & - & - \\
\hline Tidak Setuju & - & - \\
\hline Sangat Tidak Setuju & - & - \\
\hline Jumlah & $\mathbf{3 2}$ & $\mathbf{1 0 0 \%}$ \\
\hline
\end{tabular}

Sumber: Gedung Wanita Rajawali Palembang

Dari Tabel-11 dapat dilihat bahwa responden yang menjawab sangat setuju berjumlah 12 orang atau sebesar $37,5 \%$, kemudian responden yang menjawab setuju berjumlah 20 orang atau $62,5 \%$.Jadi responden yang menjawab mayoritas kearah positif. 
4. Gaji langsung yang saya terima sesuai dengan lamanya bekerja

\begin{tabular}{|l|c|c|}
\hline \multirow{2}{*}{\multicolumn{1}{c|}{ Pernyataan }} & \multicolumn{2}{c|}{ Gaji } \\
\cline { 2 - 3 } & Frekuensi & \% \\
\hline Sangat Setuju & 19 & 59,375 \\
\hline Setuju & 10 & 31,25 \\
\hline Kurang Setuju & 3 & 9,375 \\
\hline Tidak Setuju & - & - \\
\hline Sangat Tidak Setuju & - & - \\
\hline \multicolumn{1}{|c|}{ Jumlah } & $\mathbf{3 2}$ & $\mathbf{1 0 0 \%}$ \\
\hline
\end{tabular}

\section{Sumber : Gedung Wanita Rajawali Palembang}

Dari Tabel-11 dapat dilihat bahwa responden yang menjawab sangat setuju berjumlah 19 orang atau sebesar 59,375\%, kemudian responden yang menjawab setuju berjumlah 10 orang atau sebesar $31,25 \%$ dan yang menjawab kurang setuju berjumlah 3 orang atau 9,375. Jadi responden yang menjawab mayoritas kearah positif.

Variabel Insentif $\left(X_{2}\right)$

1. Insentif yang diberikan sesuai dengan kualitas pekerjaan yang dihasilkan

\begin{tabular}{|l|c|c|}
\hline \multirow{2}{*}{\multicolumn{1}{|c|}{ Pernyataan }} & \multicolumn{2}{c|}{ Insentif } \\
\cline { 2 - 3 } & Frekuensi & \% \\
\hline Sangat Setuju & 18 & 56,25 \\
\hline Setuju & 14 & 43,75 \\
\hline Kurang Setuju & - & - \\
\hline Tidak Setuju & - & - \\
\hline Sangat Tidak Setuju & - & - \\
\hline \multicolumn{1}{|c|}{ Jumlah } & $\mathbf{3 2}$ & $\mathbf{1 0 0 \%}$ \\
\hline
\end{tabular}

Sumber : Gedung Wanita Rajawali Palembang

Dari Tabel-11 dapat dilihat bahwa responden yang menjawab sangat setuju berjumlah 18 orang atau sebesar $56,25 \%$, kemudian responden yang menjawab setuju berjumlah 14 orang atau sebesar $43,75 \%$. Jadi responden yang menjawab mayoritas kearah positif.

2. Insentif yang diberikan sesuai dengan kuantitas pekerjaan yang dihasilkan

\begin{tabular}{|l|c|c|}
\hline \multirow{2}{*}{ Pernyataan } & \multicolumn{2}{|c|}{ Insentif } \\
\cline { 2 - 3 } & Frekuensi & \% \\
\hline Sangat Setuju & 16 & 50 \\
\hline Setuju & 15 & 46,875 \\
\hline Kurang Setuju & 1 & 3,125 \\
\hline Tidak Setuju & - & - \\
\hline Sangat Tidak Setuju & - & - \\
\hline Jumlah & $\mathbf{3 2}$ & $\mathbf{1 0 0 \%}$ \\
\hline
\end{tabular}

Sumber : Gedung Wanita Rajawali Palembang

Dari Tabel-11 dapat dilihat bahwa responden yang menjawab sangat setuju berjumlah 16 orang atau sebesar 50\%, kemudian responden yang menjawab setuju berjumlah 15 orang atau sebesar $46,875 \%$ dan yang menjawab kurang setuju berjumlah 1 orang atau 3,125. Jadi responden yang menjawab mayoritas kearah positif.

3. Saya dapat menyelesaikan suatu pekejaan yang diberikan dengan efektif

\begin{tabular}{|l|c|c|}
\hline \multirow{2}{*}{ Pernyataan } & \multicolumn{2}{|c|}{ Insentif } \\
\cline { 2 - 3 } & Frekuensi & \% \\
\hline Sangat Setuju & 14 & 43,75 \\
\hline Setuju & 17 & 53,125 \\
\hline
\end{tabular}




\begin{tabular}{|l|c|c|}
\hline Kurang Setuju & 1 & 3,125 \\
\hline Tidak Setuju & - & \\
\hline Sangat Tidak Setuju & - & - \\
\hline Jumlah & $\mathbf{3 2}$ & $\mathbf{1 0 0 \%}$ \\
\hline
\end{tabular}

Dari Tabel-11 dapat dilihat bahwa responden yang menjawab sangat setuju berjumlah 14 orang atau sebesar $43,75 \%$, kemudian responden yang menjawab setuju berjumlah 17 orang atau sebesar 53,125\% dan yang menjawab kurang setuju berjumlah 1 orang atau 3,125. Jadi responden yang menjawab mayoritas kearah positif.

\section{Saya dapat menyelesaikan suatu pekejaan yang diberikan dengan efisien}

\begin{tabular}{|l|c|c|}
\hline \multirow{2}{*}{\multicolumn{1}{c|}{ Pernyataan }} & \multicolumn{2}{c|}{ Insentif } \\
\cline { 2 - 3 } & Frekuensi & \% \\
\hline Sangat Setuju & 10 & 31.25 \\
\hline Setuju & 19 & 59,375 \\
\hline Kurang Setuju & 3 & 9,375 \\
\hline Tidak Setuju & - & - \\
\hline Sangat Tidak Setuju & - & - \\
\hline Jumlah & $\mathbf{3 2}$ & $\mathbf{1 0 0 \%}$ \\
\hline
\end{tabular}

\section{Sumber : Gedung Wanita Rajawali Palembang}

Dari Tabel-11 dapat dilihat bahwa responden yang menjawab sangat setuju berjumlah 10 orang atau sebesar $31,25 \%$, kemudian responden yang menjawab setuju berjumlah 19 orang atau sebesar $59,375 \%$ dan yang menjawab kurang setuju berjumlah 3 orang atau 9,375. Jadi responden yang menjawab mayoritas kearah positif.

Tabel- 7 Distribusi frekuensi pernyataan mengenai Prestasi Kerja Karyawan

VARIABEL INDEPENDENT PRESTASI KERJA KARYAWAN (Y)

Variabel Prestasi Kerja Karyawan (Y)

\begin{tabular}{|c|c|c|c|c|c|c|}
\hline No. & Pertanyaan & STS & TS & KS & $\mathbf{S}$ & SS \\
\hline 1. & Karyawan datang tepat waktu. & - & - & 5 & 12 & 15 \\
\hline 2. & $\begin{array}{l}\text { Karyawan yang baik adalah yang bekerja sesuai } \\
\text { dengan peraturan yang ada }\end{array}$ & - & - & 5 & 13 & 14 \\
\hline 3. & $\begin{array}{l}\text { Karyawan memerlukan ketrampilan khusus dalam } \\
\text { melaksanakan tugasnya }\end{array}$ & 5 & 2 & 7 & 13 & 5 \\
\hline 4. & $\begin{array}{l}\text { Setiap karyawan mempunyai kemampuan untuk } \\
\text { merubah diri menjadi lebih baik }\end{array}$ & - & - & 10 & 10 & 12 \\
\hline 5. & $\begin{array}{l}\text { Karyawan selalu meneliti kembali hasil pekerjaanya } \\
\text { sebelum diserahkan kepada pimpinan }\end{array}$ & - & - & 5 & 13 & 14 \\
\hline 6. & $\begin{array}{l}\text { Dalam melaksanakan tugas karyawan suka men } \\
\text { dengarkan kritik dan saran dari karyawan lainnya. }\end{array}$ & - & 8 & 10 & 11 & 3 \\
\hline 7. & $\begin{array}{l}\text { Dengan kepribadian yang berbeda-beda karyawan } \\
\text { sulit menyesuaikan diri }\end{array}$ & - & 6 & 13 & 11 & 2 \\
\hline 8. & $\begin{array}{l}\text { Mutu kerja karyawan dapat dilihat dari kepribadian } \\
\text { dan cara kerjanya. }\end{array}$ & 4 & 5 & 12 & 9 & 2 \\
\hline 9. & $\begin{array}{l}\text { Karyawan melaksanakan tugas tambahan yang } \\
\text { diberikan dengan penuh tanggung jawab }\end{array}$ & 3 & 3 & 12 & 10 & 4 \\
\hline 10. & $\begin{array}{l}\text { Karyawan selalu merasa kualitas kerjanya semakin } \\
\text { baik. }\end{array}$ & & 5 & 10 & 13 & 4 \\
\hline 11. & Adanya teguran bagi karyawan yang sering izin. & & 3 & 9 & 10 & 6 \\
\hline 12. & Pemberian sangsi bagi karyawan yang tidak aktif. & 6 & 6 & 7 & 9 & 4 \\
\hline 13. & Karyawan saling mengingatkan apabila ada karyawan & 2 & 4 & 7 & 7 & 12 \\
\hline
\end{tabular}




\begin{tabular}{|c|l|c|c|c|c|c|}
\hline & yang sering datang terlambat. & & & & \\
\hline 14. & $\begin{array}{l}\text { Karyawan yang sering terlambat diberi tugas } \\
\text { tambahan. }\end{array}$ & 7 & 3 & 8 & 13 & 1 \\
\hline 15. & $\begin{array}{l}\text { Karyawan diwajibkan lembur apabila pekerjaan } \\
\text { belum selesai. }\end{array}$ & 3 & 5 & 6 & 12 & 6 \\
\hline 16. & $\begin{array}{l}\text { Karyawan selalu memanfaatkan waktu kerja dengan } \\
\text { maksimal mal karya }\end{array}$ & 2 & 4 & 10 & 12 & 4 \\
\hline 17. & $\begin{array}{l}\text { Karyawan melempar tanggungjawab kepada karya } \\
\text { wan lainnya }\end{array}$ & 4 & 13 & 4 \\
\hline 18. & $\begin{array}{l}\text { Karyawan selalu mengerjakan pekerjaan dengan } \\
\text { sungguh-sungguh dan melaporkan hasilnya pada } \\
\text { pimpinan. }\end{array}$ & 1 & 6 & 9 & 4 & 12 \\
\hline
\end{tabular}

Tabel-8 Persepsi jawaban responden mengenai gaji dan insentif karyawan terhadap prestasi kerja karyawan

1. Karyawan datang tepat waktu.

\begin{tabular}{|l|c|c|}
\hline \multicolumn{1}{|c|}{ Pernyataan } & \multicolumn{2}{c|}{ Prestasi } \\
\cline { 2 - 3 } \multicolumn{1}{c|}{ Frekuensi } & \% \\
\hline Sangat Setuju & 15 & 46,875 \\
\hline Setuju & 12 & 37,5 \\
\hline Kurang Setuju & 5 & 15,625 \\
\hline Tidak Setuju & - & - \\
\hline Sangat Tidak Setuju & - & - \\
\hline \multicolumn{1}{|c|}{ Jumlah } & $\mathbf{3 2}$ & $\mathbf{1 0 0 \%}$ \\
\hline
\end{tabular}

Sumber : Gedung Wanita Rajawali Palembang

Dari Tabel-8 dapat dilihat bahwa responden yang menjawab sangat setuju berjumlah 15 orang atau sebesar $46,875 \%$, kemudian responden yang menjawab setuju berjumlah 12 orang atau $37.5 \%$ dan responden yang mengatakan kurang setuju berjumlah 5 orang atau $15,625 \%$.. Jadi responden yang menjawab mayoritas kearah positif

2. Karyawan yang baik adalah yang bekerja sesuai dengan peraturan yang ada

\begin{tabular}{|l|c|c|}
\hline \multirow{2}{*}{\multicolumn{1}{c|}{ Pernyataan }} & \multicolumn{2}{c|}{ Prestasi } \\
\cline { 2 - 3 } & Frekuensi & \% \\
\hline Sangat Setuju & 14 & 43,75 \\
\hline Setuju & 13 & 40,625 \\
\hline Kurang Setuju & 5 & 15,625 \\
\hline Tidak Setuju & - & - \\
\hline Sangat Tidak Setuju & - & - \\
\hline \multicolumn{1}{|c|}{ Jumlah } & $\mathbf{3 2}$ & $\mathbf{1 0 0 \%}$ \\
\hline
\end{tabular}

Sumber : Gedung Wanita Rajawali Palembang

Dari Tabel-8 dapat dilihat bahwa responden yang menjawab sangat setuju berjumlah 14 orang atau sebesar $43,75 \%$, kemudian responden yang menjawab setuju berjumlah 13 orang atau $40,625 \%$ dan responden yang mengatakan kurang setuju berjumlah 5 orang atau 15,625\%.. Jadi responden yang menjawab mayoritas kearah positif

3. Karyawan memerlukan ketrampilan khusus dalam melaksanakan tugasnya

\begin{tabular}{|l|c|c|}
\hline \multirow{2}{*}{\multicolumn{1}{c|}{ Pernyataan }} & \multicolumn{2}{c|}{ Prestasi } \\
\cline { 2 - 3 } & Frekuensi & \% \\
\hline Sangat Setuju & 5 & 15,625 \\
\hline Setuju & 13 & 40,625 \\
\hline Kurang Setuju & 7 & 15,625 \\
\hline
\end{tabular}




\begin{tabular}{|c|c|c|}
\hline Tidak Setuju & 2 & - \\
\hline Sangat Tidak Setuju & 5 & - \\
\hline Jumlah & $\mathbf{3 2}$ & $\mathbf{1 0 0 \%}$ \\
\hline
\end{tabular}

Sumber : Gedung Wanita Rajawali Palembang

Dari Tabel-8 dapat dilihat bahwa responden yang menjawab sangat setuju berjumlah 5 orang atau sebesar $15,625 \%$, kemudian responden yang menjawab setuju berjumlah 13 orang atau $40,625 \%$ , kemudian responden yang menjawab kurang setuju sebanyak 7 orang atau $21,875 \%$. Kemudian responden yang menjawab tidak setuju berjumlah 2 orang atau $6,25 \%$ dan responden yang menjawab sangat btidak setuju berjumlah 5 orang atau $15,625 \%$. Jadi responden yang menjawab mayoritas kearah positif.

4. Setiap karyawan mempunyai kemampuan untuk merubah diri menjadi lebih baik

\begin{tabular}{|l|c|c|}
\hline \multirow{2}{*}{\multicolumn{1}{c|}{ Pernyataan }} & \multicolumn{2}{c|}{ Prestasi } \\
\cline { 2 - 3 } & Frekuensi & \% \\
\hline Sangat Setuju & 12 & 37,5 \\
\hline Setuju & 10 & 31,25 \\
\hline Kurang Setuju & 10 & 31,25 \\
\hline Tidak Setuju & - & - \\
\hline Sangat Tidak Setuju & - & - \\
\hline \multicolumn{1}{|c|}{ Jumlah } & $\mathbf{3 2}$ & $\mathbf{1 0 0 \%}$ \\
\hline
\end{tabular}

Sumber : Gedung Wanita Rajawali Palembang

Dari Tabel-8 dapat dilihat bahwa responden yang menjawab sangat setuju berjumlah 12 orang atau sebesar $37,5 \%$, kemudian responden yang menjawab setuju dan kurang setuju berjumlah 10 orang atau sama-sama sebesar $31,25 \%$. Setiap karyawan mempunyai kemampuan untuk merubah diri menjadi lebih baik

5. Karyawan selalu meneliti kembali hasil pekerjaanya sebelum diserahkan kepada pimpinan

\begin{tabular}{|l|c|c|}
\hline \multirow{2}{*}{\multicolumn{1}{|c|}{ Pernyataan }} & \multicolumn{2}{c|}{ Prestasi } \\
\cline { 2 - 3 } & Frekuensi & \% \\
\hline Sangat Setuju & 14 & 43,75 \\
\hline Setuju & 13 & 40,625 \\
\hline Kurang Setuju & 5 & 15,625 \\
\hline Tidak Setuju & - & - \\
\hline Sangat Tidak Setuju & - & - \\
\hline \multicolumn{1}{|c|}{ Jumlah } & $\mathbf{3 2}$ & $\mathbf{1 0 0 \%}$ \\
\hline
\end{tabular}

Sumber : Gedung Wanita Rajawali Palembang

Dari Tabel-8 dapat dilihat bahwa responden yang menjawab sangat setuju berjumlah 14 orang atau sebesar $43,75 \%$, kemudian responden yang menjawab setuju berjumlah 13 orang atau sebesar $40,625 \%$ dan responden yang menjawab kurang bsetuju sebanyak 5 orang atau sebesar $15,625 \%$. Jadi responden yang menjawab mayoritas kearah positif

6. Dalam melaksanakan tugas karyawan suka men dengarkan kritik dan saran dari karyawan lainnya.

\begin{tabular}{|l|c|c|}
\hline \multirow{2}{*}{\multicolumn{1}{|c|}{ Pernyataan }} & \multicolumn{2}{c|}{ Prestasi } \\
\cline { 2 - 3 } & Frekuensi & \% \\
\hline Sangat Setuju & 3 & 43,75 \\
\hline Setuju & 11 & 40,625 \\
\hline Kurang Setuju & 10 & 15,625 \\
\hline Tidak Setuju & 8 & - \\
\hline
\end{tabular}




\begin{tabular}{|c|c|c|}
\hline Sangat Tidak Setuju & - & - \\
\hline Jumlah & $\mathbf{3 2}$ & $\mathbf{1 0 0 \%}$ \\
\hline
\end{tabular}

\section{Sumber: Gedung Wanita Rajawali Palembang}

Dari Tabel-8 dapat dilihat bahwa responden yang menjawab sangat setuju berjumlah 3 orang atau sebesar 9,375\%, kemudian responden yang menjawab setuju berjumlah 11 orang atau sebesar $34.375 \%$ dan responden yang menjawab kurang setuju berjumlah 10 orang atau sebesar $31,25 \%$. Jadi responden yang menjawab mayoritas kearah positif

Tabel-7 Dengan kepribadian yang berbeda-beda karyawan sulit menyesuaikan diri

\begin{tabular}{|l|c|c|}
\hline \multirow{2}{*}{\multicolumn{1}{|c|}{ Pernyataan }} & \multicolumn{2}{c|}{ Prestasi } \\
\cline { 2 - 3 } & Frekuensi & \% \\
\hline Sangat Setuju & 2 & 6,25 \\
\hline Setuju & 11 & 34,375 \\
\hline Kurang Setuju & 13 & 3,125 \\
\hline Tidak Setuju & 6 & 18,75 \\
\hline Sangat Tidak Setuju & - & - \\
\hline \multicolumn{1}{|c|}{ Jumlah } & $\mathbf{3 2}$ & $\mathbf{1 0 0 \%}$ \\
\hline
\end{tabular}

Sumber : Gedung Wanita Rajawali Palembang

Dari Tabel-8 dapat dilihat bahwa responden yang menjawab sangat setuju berjumlah 2 orang atau sebesar $6,25 \%$, kemudian responden yang menjawab setuju berjumlah 11 orang atau sebesar $34,375 \%$ dan yang menjawab kurang setuju berjumlah 13 orang atau sebesar $3,125 \%$ dan yang menjawab tidak setuju ada 6 orang atau sebesar 18,75\% . Jadi responden yang menjawab mayoritas kearah positif.

1. Mutu kerja karyawan dapat dilihat dari kepribadian dan cara kerjanya.

\begin{tabular}{|l|c|c|}
\hline \multirow{2}{*}{\multicolumn{1}{|c|}{ Pernyataan }} & \multicolumn{2}{c|}{ Prestasi } \\
\cline { 2 - 3 } & Frekuensi & \% \\
\hline Sangat Setuju & 19 & 59,375 \\
\hline Setuju & 10 & 31,25 \\
\hline Kurang Setuju & 3 & 9,375 \\
\hline Tidak Setuju & - & - \\
\hline Sangat Tidak Setuju & - & $\mathbf{1 0 0 \%}$ \\
\hline \multicolumn{1}{|c|}{ Jumlah } & $\mathbf{3 2}$ & \\
\hline
\end{tabular}

Sumber : Gedung Wanita Rajawali Palembang

Dari Tabel-8 dapat dilihat bahwa responden yang menjawab sangat setuju berjumlah 19 orang atau sebesar $59,375 \%$, kemudian responden yang menjawab setuju berjumlah 10 orang atau sebesar $31,25 \%$ dan yang menjawab kurang setuju berjumlah 3 orang atau 9,375. Jadi responden yang menjawab mayoritas kearah positif.

\section{Karyawan melaksanakan tugas tambahan yang diberikan dengan penuh tanggung jawab}

\begin{tabular}{|l|c|c|}
\hline \multirow{2}{*}{\multicolumn{1}{|c|}{ Pernyataan }} & \multicolumn{2}{c|}{ Prestasi } \\
\cline { 2 - 3 } & Frekuensi & \% \\
\hline Sangat Setuju & 4 & 12,5 \\
\hline Setuju & 10 & 31,25 \\
\hline Kurang Setuju & 12 & 37,5 \\
\hline Tidak Setuju & 3 & 9,375 \\
\hline Sangat Tidak Setuju & 3 & 9,375 \\
\hline \multicolumn{1}{|c|}{ Jumlah } & $\mathbf{3 2}$ & $\mathbf{1 0 0 \%}$ \\
\hline
\end{tabular}

Sumber : Gedung Wanita Rajawali P alembang 
Dari Tabel-8 dapat dilihat bahwa responden yang menjawab sangat setuju berjumlah 4 orang atau sebesar $12,5 \%$, kemudian responden yang menjawab setuju berjumlah 10 orang atau sebesar $31,25 \%$ dan yang menjawab kurang setuju berjumlah 12 orang atau 37,5. Jadi responden yang menjawab mayoritas kearah positif.

\section{Karyawan selalu merasa kualitas kerjanya semakin baik}

\begin{tabular}{|l|c|c|}
\hline \multirow{2}{*}{\multicolumn{1}{|c|}{ Pernyataan }} & \multicolumn{2}{c|}{ Prestasi } \\
\cline { 2 - 3 } & Frekuensi & \% \\
\hline Sangat Setuju & 19 & 59,375 \\
\hline Setuju & 10 & 31,25 \\
\hline Kurang Setuju & 3 & 9,375 \\
\hline Tidak Setuju & - & - \\
\hline Sangat Tidak Setuju & - & - \\
\hline \multicolumn{1}{|c|}{ Jumlah } & $\mathbf{3 2}$ & $\mathbf{1 0 0 \%}$ \\
\hline
\end{tabular}

Sumber: Gedung Wanita Rajawali Palembang

Dari Tabel-8 dapat dilihat bahwa responden yang menjawab sangat setuju berjumlah 19 orang atau sebesar 59,375\%, kemudian responden yang menjawab setuju berjumlah 10 orang atau sebesar $31,25 \%$ dan yang menjawab kurang setuju berjumlah 3 orang atau 9,375. Jadi responden yang menjawab mayoritas kearah positif.

4. Adanya teguran bagi karyawan yang sering izin.

\begin{tabular}{|l|c|c|}
\hline \multirow{2}{*}{\multicolumn{1}{|c|}{ Pernyataan }} & \multicolumn{2}{c|}{ Prestasi } \\
\cline { 2 - 3 } & Frekuensi & \% \\
\hline Sangat Setuju & 6 & 18,75 \\
\hline Setuju & 10 & 31,25 \\
\hline Kurang Setuju & 9 & 28,125 \\
\hline Tidak Setuju & 3 & 9,375 \\
\hline Sangat Tidak Setuju & 4 & 12,5 \\
\hline \multicolumn{1}{|c|}{ Jumlah } & $\mathbf{3 2}$ & $\mathbf{1 0 0 \%}$ \\
\hline
\end{tabular}

Dari Tabel-8 dapat dilihat bahwa responden yang menjawab sangat setuju berjumlah 6 orang atau sebesar $18,75 \%$, kemudian responden yang menjawab setujuberjumlah 10 orang atau sebesar $31,25 \%$ dan yang menjawab kurang setuju berjumlah 9 orang atau 28,125. Kemudian responden yang menjawab setuju berjumlah 3 orang atau sebesar 9,375\% dan yang menjawab sangat tidak setuju berjumlah 4 orang atau sebesar 12,5. Jadi responden yang menjawab mayoritas kearah positif.

12. Pemberian sangsi bagi karyawan yang tidak aktif.

\begin{tabular}{|l|c|c|}
\hline \multirow{2}{*}{\multicolumn{1}{|c|}{ Pernyataan }} & \multicolumn{2}{c|}{ Prestasi } \\
\cline { 2 - 3 } & Frekuensi & \% \\
\hline Sangat Setuju & 4 & 12,5 \\
\hline Setuju & 9 & 28,125 \\
\hline Kurang Setuju & 7 & 21,875 \\
\hline Tidak Setuju & 6 & 18,75 \\
\hline Sangat Tidak Setuju & 6 & 18,75 \\
\hline \multicolumn{1}{|c|}{ Jumlah } & $\mathbf{3 2}$ & $\mathbf{1 0 0 \%}$ \\
\hline
\end{tabular}

Sumber: Gedung Wanita Rajawali Palembang

Dari Tabel-8 dapat dilihat bahwa responden yang menjawab sangat setuju berjumlah 4 orang atau sebesar $12,5 \%$, kemudian responden yang menjawab setuju berjumlah 9 orang atau sebesar $28,125 \%$ dan yang menjawab kurang setuju berjumlah 7 orang atau sebesar 21,875. Kemudian responden yang menjawab tidak setuju berjumlah 6 orang atau sebesar $18,75 \%$ dan yang menjawab 
sangat tidak setuju berjumlah 6 orang atau sebesar 18,75 juga. Jadi responden yang menjawab mayoritas kearah positif.

13. Karyawan saling mengingatkan apabila ada karyawan yang sering datang terlambat

\begin{tabular}{|l|c|c|}
\hline \multirow{2}{*}{\multicolumn{1}{|c|}{ Pernyataan }} & \multicolumn{2}{c|}{ Prestasi } \\
\cline { 2 - 3 } & Frekuensi & \% \\
\hline Sangat Setuju & 12 & 37,5 \\
\hline Setuju & 7 & 21,875 \\
\hline Kurang Setuju & 7 & 21,875 \\
\hline Tidak Setuju & 4 & 12,5 \\
\hline Sangat Tidak Setuju & 2 & 6,25 \\
\hline \multicolumn{1}{|c|}{ Jumlah } & $\mathbf{3 2}$ & $\mathbf{1 0 0 \%}$ \\
\hline
\end{tabular}

Sumber : Gedung Wanita Rajawali Palembang

Dari Tabel-8 dapat dilihat bahwa responden yang menjawab sangat setuju berjumlah 12 orang atau sebesar 37,5\%, kemudian responden yang menjawab setuju berjumlah 7 orang atau sebesar $21,875 \%$ dan yang menjawab kurang setuju juga berjumlah 7 orang atau sebesar 21,875. Respondenn yang menjawab sangat tidak setuju sebanyak 2 orang atau sebesar $6,25 \%$. Jadi responden yang menjawab mayoritas ke arah positif.

14. Karyawan yang sering terlambat diberi tugas tambahan.

\begin{tabular}{|l|c|c|}
\multirow{2}{*}{\multicolumn{1}{c|}{ Pernyataan }} & \multicolumn{2}{c|}{ Prestasi } \\
\cline { 2 - 3 } & Frekuensi & \% \\
\hline Sangat Setuju & 19 & 59,375 \\
\hline Setuju & 10 & 31,2 \\
\hline Kurang Setuju & 3 & 9,375 \\
\hline Tidak Setuju & - & - \\
\hline Sangat Tidak Setuju & - & - \\
\hline \multicolumn{1}{|c|}{ Jumlah } & $\mathbf{3 2}$ & $\mathbf{1 0 0 \%}$ \\
\hline
\end{tabular}

Sumber : Gedung Wanita Rajawali Palembang

Dari Tabel-8 dapat dilihat bahwa responden yang menjawab sangat setuju berjumlah 19 orang atau sebesar 59,375\%, kemudian responden yang menjawab setuju berjumlah 10 orang atau sebesar $31,25 \%$ dan yang menjawab kurang setuju berjumlah 3 orang atau 9,375. Jadi responden yang menjawab mayoritas kearah positif.

15. Karyawan diwajibkan lembur apabila pekerjaan belum selesai.

\begin{tabular}{|l|c|c|}
\hline \multirow{2}{*}{\multicolumn{1}{c|}{ Pernyataan }} & \multicolumn{2}{c|}{ Prestasi } \\
\cline { 2 - 3 } & Frekuensi & \% \\
\hline Sangat Setuju & 6 & 18,75 \\
\hline Setuju & 12 & 37,5 \\
\hline Kurang Setuju & 5 & 15,625 \\
\hline Tidak Setuju & 3 & 9,375 \\
\hline Sangat Tidak Setuju & - & - \\
\hline \multicolumn{1}{|c|}{ Jumlah } & $\mathbf{3 2}$ & $\mathbf{1 0 0 \%}$ \\
\hline
\end{tabular}

Sumber : Gedung Wanita Rajawali Palembang

Dari Tabel-8 dapat dilihat bahwa responden yang menjawab sangat setuju berjumlah 6 orang atau sebesar $18,75 \%$, kemudian responden yang menjawab setuju berjumlah 12 orang atau sebesar $37,55 \%$ dan yang menjawab kurang setuju berjumlah 5 orang atau $15,625 \%$. Jdan yang maenjawab sangatb tidak setuju sebanyak 3 orang atau sebesar 9,375\% . Jadi responden yang menjawab mayoritas kearah positif. 
16. Karyawan selalu memanfaatkan waktu kerja dengan maksimal

\begin{tabular}{|l|c|c|}
\hline \multirow{2}{*}{\multicolumn{1}{c|}{ Pernyataan }} & \multicolumn{2}{c|}{ Prestasi } \\
\cline { 2 - 3 } & Frekuensi & \% \\
\hline Sangat Setuju & 4 & 12,5 \\
\hline Setuju & 12 & 37,5 \\
\hline Kurang Setuju & 10 & 31,25 \\
\hline Tidak Setuju & 4 & 12,5 \\
\hline Sangat Tidak Setuju & 2 & 6,25 \\
\hline \multicolumn{1}{|c|}{ Jumlah } & $\mathbf{3 2}$ & $\mathbf{1 0 0 \%}$ \\
\hline
\end{tabular}

\section{Sumber : Gedung Wanita Rajawali Palembang}

Dari Tabel-8 dapat dilihat bahwa responden yang menjawab sangat setuju berjumlah 4 orang atau sebesar $12,5 \%$, kemudian responden yang menjawab setuju berjumlah 12 orang atau sebesar 37,5\% dan yang menjawab kurang setuju berjumlah 10 orang atau sebesar $31,25 \%$. Kemudian responden yang menjawab tidak setuju berjumlah 4 orang atau sebesar $12,5 \%$ dan yang mejawab sangat tidak setuju berjumlah 2 orang atau sebesar $6,25 \%$ Jadi responden yang menjawab mayoritas kearah positif.

\section{Karyawan melempar tanggungjawab kepada karya wan lainnya}

\begin{tabular}{|l|c|c|}
\hline \multirow{2}{*}{\multicolumn{1}{c|}{ Pernyataan }} & \multicolumn{2}{c|}{ Prestasi } \\
\cline { 2 - 3 } & Frekuensi & \% \\
\hline Sangat Setuju & 4 & 12,5 \\
\hline Setuju & 13 & 40,62 \\
\hline Kurang Setuju & 4 & 12,5 \\
\hline Tidak Setuju & 9 & 28,125 \\
\hline Sangat Tidak Setuju & 2 & 6,25 \\
\hline \multicolumn{1}{|c|}{ Jumlah } & $\mathbf{3 2}$ & $\mathbf{1 0 0 \%}$ \\
\hline
\end{tabular}

\section{Sumber : Gedung Wanita Rajawali Palembang}

Dari Tabel-8 dapat dilihat bahwa responden yang menjawab sangat setuju berjumlah 4 orang atau sebesar $12,5 \%$, kemudian responden yang menjawab setuju berjumlah 13 orang atau sebesar $40,625 \%$ dan responden yang menjawab kurang setuju berjumlah 4 orang atau 12,5 dan yang menjawab sangat tidak setuju ada 2 orang atau sebesar 6,25\%. Jadi responden yang menjawab mayoritas kearah positif.

18. Karyawan selalu mengerjakan pekerjaan dengan sungguh-sungguh dan melaporkan hasilnya pada pimpinan

\begin{tabular}{|l|c|c|}
\hline \multirow{2}{*}{\multicolumn{1}{|c|}{ Pernyataan }} & \multicolumn{2}{c|}{ Prestasi } \\
\cline { 2 - 3 } & Frekuensi & \% \\
\hline Sangat Setuju & 12 & 37,5 \\
\hline Setuju & 4 & 12,5 \\
\hline Kurang Setuju & 9 & 28,125 \\
\hline Tidak Setuju & 6 & 18,75 \\
\hline Sangat Tidak Setuju & 1 & \\
\hline \multicolumn{1}{|c|}{ Jumlah } & $\mathbf{3 2}$ & $\mathbf{1 0 0 \%}$ \\
\hline
\end{tabular}

\section{Sumber : Gedung Wanita Rajawali Palembang}

Dari Tabel-8 dapat dilihat bahwa responden yang menjawab sangat setuju berjumlah 12 orang atau sebesar $37,5 \%$, kemudian responden yang menjawab setuju berjumlah 4 orang atau sebesar $12,5 \%$ dan yang menjawab kurang setuju berjumlah 9 orang atau sebesar $28,125 \%$ dan yang menjawab tidak setuju berjumlah 6 orang atau sebesar 18,75 dan responden yang menjawab sangat tidak setuju ada 1 orang atau sebesar $3,125 \%$. Jadi responden yang menjawab mayoritas kearah positif. 


\section{Uji Statistik/Analisis Data}

\section{Uji Validitas}

Uji Validitas digunakan untuk mengukur ketepatan atau kecermatan suatu instrument penelitian, menurut Dwi (2009:90) dalam penentuan layak atau tidaknya suatu item yang digunakan biasanya dilakukan uji signifikan, artinya dianggap valid jika berkorelasi signifikan terhadap total, atau jika melakukan penilaian langsung jika batas minimal korelasi 0,30. Dalam hubungannnya dengan uraian tersebut diatas maka perlu dilakukan uji validitas untuk setiap variabel yang akan digunakan dalam pengujian hipotesis. Oleh karena itulah akan disajikan uji validitas untuk variabel Gaji.Insentif dan Prestasi Kerja yang dapat disajikan pada tabel berikut ini :

Tabel-9 Hasil Pengujian Validitas atas butir pertanyaan

\begin{tabular}{|c|c|c|c|c|}
\hline Variabel & Korelasi & Sig & $\begin{array}{c}\text { Batas } \\
\text { Minimal } \\
\text { Korelasi }\end{array}$ & Keterangan \\
\hline \multicolumn{5}{|l|}{ Gaji $\left(X_{1}\right)$} \\
\hline Gaji1 & 0,651 & 0,000 & 0,30 & Valid \\
\hline Gaji2 & 0,723 & 0,000 & 0,30 & Valid \\
\hline Gaji3 & 0,777 & 0,000 & 0,30 & Valid \\
\hline Gaji4 & 0,611 & 0,000 & 0,30 & Valid \\
\hline \multicolumn{5}{|l|}{$\begin{array}{c}\text { Insentif } \\
\left(\mathrm{X}_{2}\right)\end{array}$} \\
\hline Insentif1 & 0,775 & 0,000 & 0,30 & Valid \\
\hline Insentif2 & 0,785 & 0,000 & 0,30 & Valid \\
\hline Insentif3 & 0,837 & 0,000 & 0,30 & Valid \\
\hline Insentif4 & 0,481 & 0,000 & 0,30 & Valid \\
\hline & & & & \\
\hline \multicolumn{5}{|l|}{$\begin{array}{c}\text { Prestasi } \\
\text { kerja (Y) }\end{array}$} \\
\hline PK 1 & 0,071 & 0,000 & 0,30 & Valid \\
\hline PK2 & 0,424 & 0,000 & 0,30 & Valid \\
\hline PK3 & 0,159 & 0,000 & 0,30 & Valid \\
\hline PK4 & 0,377 & 0,000 & 0,30 & Valid \\
\hline PK5 & 0,407 & 0,000 & 0,30 & Valid \\
\hline PK6 & 0,317 & 0,000 & 0,30 & Valid \\
\hline PK7 & 0,392 & 0,000 & 0,30 & Valid \\
\hline PK8 & 0,541 & 0,000 & 0,30 & Valid \\
\hline PK9 & 0,406 & 0,000 & 0,30 & Valid \\
\hline PK10 & 0,295 & 0,000 & 0,30 & Valid \\
\hline PK11 & 0,487 & 0,000 & 0,30 & Valid \\
\hline PK12 & 0,151 & 0,000 & 0,30 & Valid \\
\hline PK13 & 0,042 & 0,000 & 0,30 & Valid \\
\hline PK14 & 0,303 & 0,000 & 0,30 & Valid \\
\hline PK15 & 0,392 & 0,000 & 0,30 & Valid \\
\hline PK16 & 0,541 & 0,000 & 0,30 & Valid \\
\hline PK17 & 0,071 & 0,000 & 0,30 & Valid \\
\hline PK18 & 0,424 & 0,000 & 0,30 & Valid \\
\hline
\end{tabular}

Sumber : Hasil Olahan Data SPSS 15 
Berdasarkan hasil peangujian validitas pada tabel 14 diketahui seluruh butir pernyataan variabel prestasi kerja menunjukkan nilai $r$ hitung lebih besar dari $r$ table $(0,30)$ dengan nilai terendah 0,071 dan tertinggi 0,837 . Dengan demikian keseluruhan butir pernyataan variabel diatas dinyatakan valid dan memenuhi syarat sebagai alat ukur variabel prestasi kerja.

\section{Uji Reliabilitas}

Uji reliabilitas digunakan untuk mengetahui konsistensi alat ukur, apakah alat ukur yang digunakan dapat diandalkan dan tetap konsisten jika pengukuran tersebut diulang. Oleh karena nitulah akan disajikan hasil uji reliabilitas yang dapat dilihat pada tabel berikut ini

Tabel-10. Hasil Pengujian Reabilitas untuk setiap variabel.

\begin{tabular}{|c|c|c|c|}
\hline Variabel & $\begin{array}{l}\text { Cronbach's } \\
\text { Alpha }\end{array}$ & $\begin{array}{c}\text { Cronbach's } \\
\text { Alpha Standart }\end{array}$ & Keterangan \\
\hline $\begin{array}{c}\text { Gaji }\left(\mathbf{X}_{1}\right) \\
\text { Gaji1 } \\
\text { Gaji2 } \\
\text { Gaji3 } \\
\text { Gaji4 }\end{array}$ & $\begin{array}{l}0,755 \\
0,730 \\
0,711 \\
0,763 \\
\end{array}$ & $\begin{array}{l}0,60 \\
0,60 \\
0,60 \\
0,60\end{array}$ & $\begin{array}{l}\text { Reliabel } \\
\text { Reliabel } \\
\text { Reliabel } \\
\text { Reliabel }\end{array}$ \\
\hline $\begin{array}{c}\text { Insentif } \\
\left(\mathbf{X}_{\mathbf{2}}\right) \\
\text { Insentif1 } \\
\text { Insentif2 }\end{array}$ & $\begin{array}{l}0,725 \\
0,714\end{array}$ & $\begin{array}{l}0,60 \\
0,60\end{array}$ & $\begin{array}{l}\text { Reliabel } \\
\text { Reliabel }\end{array}$ \\
\hline $\begin{array}{l}\text { Insentif3 } \\
\text { Insentif4 }\end{array}$ & $\begin{array}{l}0,677 \\
0,782\end{array}$ & $\begin{array}{l}0,60 \\
0,60\end{array}$ & $\begin{array}{l}\text { Reliabel } \\
\text { Reliabel }\end{array}$ \\
\hline $\begin{array}{c}\text { Prestasi } \\
\text { kerja (Y) }\end{array}$ & & & \\
\hline $\begin{array}{l}\text { PK 1 } \\
\text { PK2 } \\
\text { PK3 } \\
\text { PK4 }\end{array}$ & $\begin{array}{l}0,851 \\
0,861 \\
0,856 \\
0,845\end{array}$ & $\begin{array}{l}0,60 \\
0,60 \\
0,60 \\
0,60\end{array}$ & $\begin{array}{l}\text { Reliabel } \\
\text { Reliabel } \\
\text { Reliabel } \\
\text { Reliabel }\end{array}$ \\
\hline PK5 & 0,858 & 0,60 & Reliabel \\
\hline PK6 & 0,845 & 0,60 & Reliabel \\
\hline PK7 & 0,841 & 0,60 & Reliabel \\
\hline PK8 & 0,854 & 0,60 & Reliabel \\
\hline PK9 & 0,844 & 0,60 & Reliabel \\
\hline PK10 & 0,854 & 0,60 & Reliabel \\
\hline PK11 & 0,842 & 0,60 & Reliabel \\
\hline PK12 & 0,861 & 0,60 & Reliabel \\
\hline PK13 & 0,866 & 0,60 & Reliabel \\
\hline PK14 & 0,870 & 0,60 & Reliabel \\
\hline PK15 & 0,841 & 0,60 & Reliabel \\
\hline PK16 & 0,854 & 0,60 & Reliabel \\
\hline PK17 & 0,851 & 0,60 & Reliabel \\
\hline PK18 & 0,861 & 0,60 & Reliabel \\
\hline
\end{tabular}

Sumber : Hasil Olahan Data SPSS 1 
Berdasarkan hasil uji reliabilitas pada variabel gaji dan insentif dan variabel prestasi kerja, seluruhnya menunjukkan nilai Cronbach Alpha berada diatas 0,60. Hasil ini berarti alat ukur yang digunakan memenuhi syarat dan dapat diandalkan. Dalam hal ini bila Realibilty Coefficient (Alpha) nilainya $>0,60$ dan butir yang diukur dapat dipercaya atau diandalkan.

\section{Analisis Regresi Linier Berganda}

Berdasarkan hasil analisis data dalam penelitian ini menggunakan metode regresi linier berganda, dimana variabel-variabel independen yang diduga mempengaruhi Gaji dan Insentif dibatasi dua variabel saja. Variabel yang dianalisis yaitu Prestasi kerja karyawan. Variabel tersebut dianalisis dengan menggunakan metode analisis regresi linier berganda dengan menggunakan program "SPSS". Tujuan pengujian adalah untuk menguji kebenaran hipotesis variabel tersebut diatas dan melihat bagaimana hubungan dari variabel Prestasi Kerja Karyawan terhadap gaji dan insentif. Hasil analisis dengan model regresi linier berganda terhadap Prestasi Kerja karyaawan (Y) sebagai dependen dengan variabel Gaji $\left(\mathrm{X}_{1}\right)$ dan insentif $\left(\mathrm{X}_{2}\right)$ sebagai independen variabel, secara lengkap ditampilkan pada tabel berikut :

\begin{tabular}{|c|c|c|c|}
\multicolumn{1}{c|}{ Descriptive Statistics } \\
& Mean & $\begin{array}{c}\text { Std. } \\
\text { Deviation }\end{array}$ & $\mathrm{N}$ \\
\hline Pres.Kerja_ & 63,66 & 9,276 & 32 \\
Y & 14,56 & 3,172 & 32 \\
Gaji_X1 & 14,41 & 3,732 & 32 \\
Insentif_X2 & &
\end{tabular}

\section{- Tabel Pada Descriptive Statistics:}

Menunjukkan berapa besar nilairat-rata (mean) dan std. deviation variabel bebas dan variabel terikat dimana gaji dan insentif nilai mean sebesar 14,56 dan 14,41dan standar deviationnya 3,172 dan 3,732 sedangkan nilai mean prestasi kerja 63,66 dan 9,276 untuk std. Deviationnya.

Variables Entered/Removed(b)

\begin{tabular}{|l|l|c|l|}
\hline $\begin{array}{l}\text { Mo } \\
\text { del }\end{array}$ & $\begin{array}{c}\text { Variables } \\
\text { Entered }\end{array}$ & $\begin{array}{c}\text { Variables } \\
\text { Removed }\end{array}$ & Method \\
\hline 1 & $\begin{array}{l}\text { Insentif_X2, } \\
\text { Gaji_X1(a) }\end{array}$ & & Enter \\
\hline
\end{tabular}

a All requested variables entered.

b Dependent Variable: Pres.Kerja_Y

Menunjukkan variabel apa saja yang diproses, mana yang menjadi vaariabel bebas dan variabel terikat :

Variabel bebas : Gaji $\left(\mathrm{X}_{1}\right)$

Variabeal Terikat : Prestasi kerja Karyawan (Y)

Model Summary(b)

\begin{tabular}{l|c|r|r|r|}
\hline Model & R & R Square & $\begin{array}{c}\text { Adjusted } \\
\text { R Square }\end{array}$ & $\begin{array}{c}\text { Std. Error of } \\
\text { the Estimate }\end{array}$ \\
\hline 1 &, $059(\mathrm{a})$ &, 003 &,- 065 & 9,574 \\
\hline
\end{tabular}
a Predictors: (Constant), Insentif_X2, Gaji_X1
b Dependent Variable: Pres.Kerja_Y

\section{- Tabel Model Summary:}

Menunjukkan besarnya koefisien determinasi yang berfungsi untuk mengetahui besarnya persentase variabel terikat prestasi kerja yang dapat diprediksi dengan menggunakan variabel bebas Gaji dan Insentif. Koefisien determinasi juga digunakan untuk menghitung besarnya pengaruh 
variabel bebas terhadap varibel terikat yaitu prestasi kerja. Koefisien determinasi dihitung dengan cara mengkuadratkan hasil korelasi, kemudian dikalikan dengan 100\%. Besarnya angka koefisien determinasi 0,59 atau sama dengan 59,0\%. Angka tersebut berarti bahwa sebesar 59,0\% prestasi kerja karyawan dapat dijelaskan dengan menggunakan variabel Gaji dan Insentif . Sedangan sisanya 41\% $(100 \%-59,0 \%)$ dijelaskan oleh faktor-faktor lain yang tidak diteliti dalam penelitian ini

\begin{tabular}{|ll|r|r|r|r|l|}
\hline \multicolumn{2}{|c|}{ Model } & & \multicolumn{1}{|c|}{ Sum of } & & & \\
\hline 1 & Squares & df & Mean Square & F & Sig. \\
\hline & Regression & 9,278 & 2 & 4,639 &, 051 &, $951(\mathrm{a})$ \\
& Residual & 2657,940 & 29 & 91,653 & & \\
& Total & 2667,219 & 31 & & & \\
\hline
\end{tabular}

a Predictors: (Constant), Insentif_X2, Gaji_X1

b Dependent Variable: Pres.Kerja_Y

\section{- $\quad$ Tabel ANOVA}

Digunakan untuk menentukan taraf signifikansi atau linieritas dan regresi, kriterianya dapat ditentukan berdasarkan uji $\mathrm{F}$ atau Uji nilai signifikan (sig). Cara yang paling mudah dengan uji sig dengan ketentuan. Jika nilai signifikan $<0,05$, maka model regresi adalah linier dan berlaku sebaliknya. Berdasarkan tabel diatas diperoleh sig 0,951, yang berarti $<$ kriteria signifikan $(0,05)$. Dengan demikian model persamaan regresi berdasarkan data penelitian adalah signifikan, artinya model regresi linier berganda dipengaruhi / memiliki kriteria linieritas

\section{Coefficients(a)}

\begin{tabular}{|c|c|c|c|c|c|c|c|c|}
\hline \multirow{2}{*}{\multicolumn{2}{|c|}{ Model }} & \multicolumn{2}{|c|}{$\begin{array}{c}\text { Unstandardized } \\
\text { Coefficients }\end{array}$} & \multirow{2}{*}{$\begin{array}{c}\text { Standardized } \\
\text { Coefficients } \\
\text { Beta }\end{array}$} & \multirow{2}{*}{$\begin{array}{c}\mathrm{t} \\
\text { Tolerance }\end{array}$} & \multirow{2}{*}{$\begin{array}{l}\text { Sig. } \\
\text { VIF }\end{array}$} & \multicolumn{2}{|c|}{ Collinearity Statistics } \\
\hline & & $\mathrm{B}$ & Std. Error & & & & $\mathrm{B}$ & Std. Error \\
\hline \multirow[t]{3}{*}{1} & (Constant) & 63,110 & 13,411 & & 4,706 &, 000 & & \\
\hline & Gaji_X1 &,- 072 &, 592 &,- 025 &,- 122 & ,904 & ,839 & 1,192 \\
\hline & ${ }_{2}^{\text {Insentif_X }}$ & ,111 & ,503 & ,045 & ,220 &, 827 & ,839 & 1,192 \\
\hline
\end{tabular}

a Dependent Variable: Pres.Kerja_Y

\section{- Tabel Cooefficients ${ }^{a}$}

Metode persamaan regresi yang diperoleh dengan koefisien konstanta dan koefisien variabel yang ada di kolom understandarized koefisien B, yaitu :$$
Y=a+\beta x_{1}+\beta x_{2}
$$

$Y=63,110+0,072 X_{1}+0,111 X_{2}$

Persamaan regresi tersebut dapat dijelaskan sebagai berikut :

a. = angka konstanta dari unstandardized coefficient yang dalam penelitian ini sebesar 63,110 angka ini berupa angka konstanta yang mempunyai arti :

Jika ada penambahan satu satuan Gaji dan Insentif , maka prestasi kerja kan bertambah 63,110

$\mathrm{bX}_{1}=$ angka koefisien regresi sebesar 0,072, angka tersebut mempunyai arti bahwa setiap penambahan 1 satuan Gaji dan Insentif, maka Prestasi Kerja Karyawan akan bertambah sebesar 0,072 demikian pula sebaliknya.

$\mathrm{bX}_{2}=$ angka koefisien regresi sebesar 0,111, angka tersebut mempunyai arti bahwa setiap penambahan 1 satuan Gaji dan Insentif, maka Prestasi Kerja Karyawan akan bertambah sebesar 0,111 demikian pula sebaliknya. 
Dari hasil persamaan regresi linier berganda yang telah diuraikan diatas, maka dengan nilai koefisien 0,072 dan 0,111 menunjukkan bahwa Gaji dan Insentif berpengaruh positif dengan Prestasi Kerja Karyawan. Dimana semakin baik pelaksanaan Gaji dan Insentif Karyawan maka akan mempengaruhi prestasi kerja karyawan dan dapat maeningkatkan prestasi kerja karyawan

Collinearity Diagnostics(a)

\begin{tabular}{|c|c|c|c|c|c|c|}
\hline \multirow[b]{2}{*}{ Model } & \multirow[b]{2}{*}{ Dimension } & \multirow{2}{*}{$\begin{array}{l}\text { Eigenvalue } \\
\text { (Constant) }\end{array}$} & \multirow{2}{*}{$\begin{array}{c}\begin{array}{c}\text { Condition } \\
\text { Index }\end{array} \\
\text { Gaji_X1 }\end{array}$} & \multicolumn{3}{|c|}{ Variance Proportions } \\
\hline & & & & $\begin{array}{c}\text { Insentif_X } \\
2\end{array}$ & (Constant) & Gaji_X1 \\
\hline 1 & 1 & 2,916 & 1,000 &, 00 &, 00 &, 01 \\
\hline & 2 & ,074 & 6,289 &, 00 & ,23 & ,38 \\
\hline & 3 &, 010 & 16,691 & 1,00 & ,77 & ,62 \\
\hline
\end{tabular}

a Dependent Variable: Pres.Kerja_Y

\section{Residuals Statistics(a)}

\begin{tabular}{|l|r|r|r|r|r|}
\hline & Minimum & $\begin{array}{c}\text { Maximu } \\
\mathrm{m}\end{array}$ & \multicolumn{1}{c|}{ Mean } & \multicolumn{1}{c|}{$\begin{array}{c}\text { Std. } \\
\text { Deviation }\end{array}$} & $\mathrm{N}$ \\
\hline Predicted Value & 62,55 & 65,09 & 63,66 &, 547 & 32 \\
Std. Predicted Value & $-2,014$ & 2,616 &, 000 & 1,000 & 32 \\
Standard Error of & 1,712 & 5,989 & 2,767 &, 984 & 32 \\
Predicted Value & & & & & \\
Adjusted Predicted & 60,39 & 68,00 & 63,58 & 1,255 & 32 \\
Value & $-26,729$ & 15,224 &, 000 & 9,260 & 32 \\
Residual & $-2,792$ & 1,590 &, 000 &, 967 & 32 \\
Std. Residual & $-2,868$ & 1,710 &, 004 & 1,010 & 32 \\
Stud. Residual & $-28,200$ & 17,608 &, 075 & 10,119 & 32 \\
Deleted Residual & $-3,329$ & 1,772 &,- 003 & 1,062 & 32 \\
Stud. Deleted Residual &, 022 & 11,164 & 1,938 & 2,392 & 32 \\
Mahal. Distance &, 000 &, 153 &, 031 &, 043 & 32 \\
Cook's Distance &, 001 &, 360 &, 063 &, 077 & 32 \\
Centered Leverage & & & & & \\
Value & & &
\end{tabular}

a Dependent Variable: Pres.Kerja_Y

\section{Charts}

Scatterplot

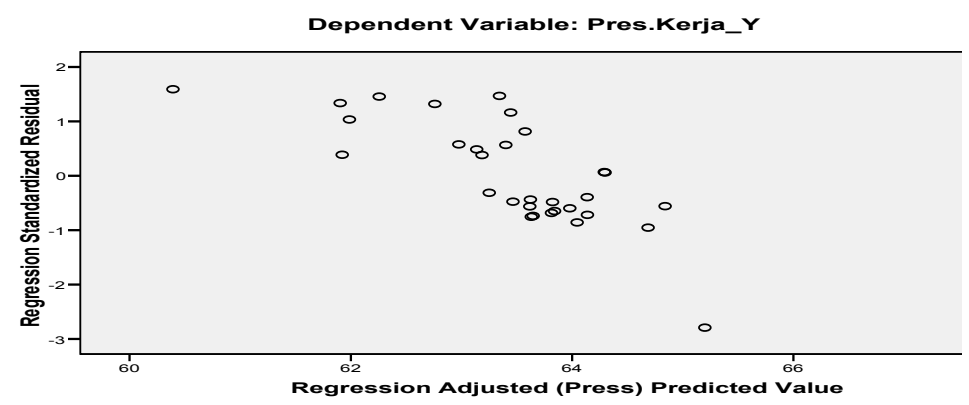


Dependent Variable: Pres.Kerja_Y

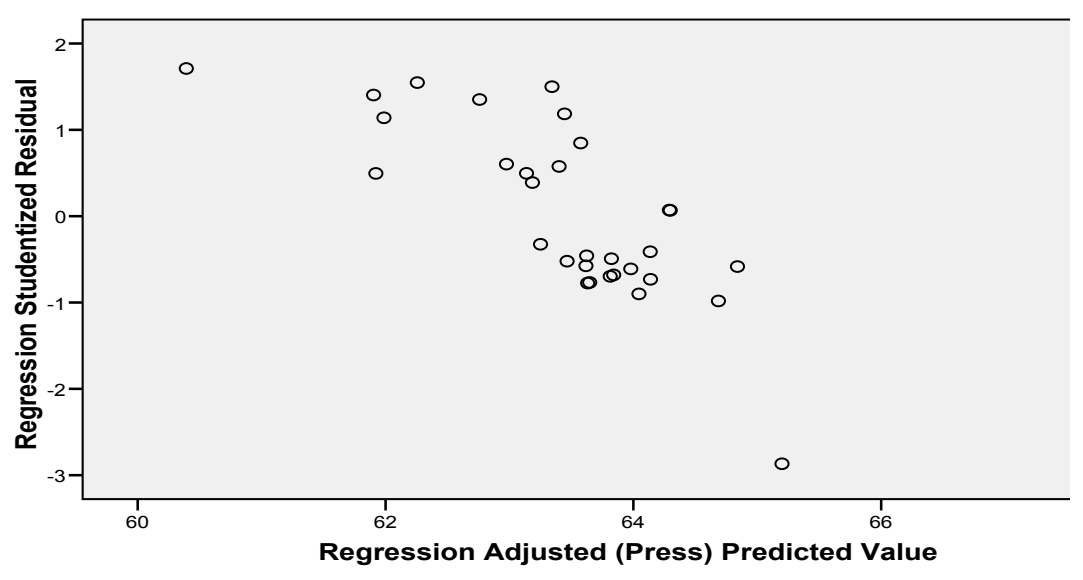

\subsection{Pembahasan}

Berdasarkan hasil analaisis yaitu pengujian regresi sederhana dan secara simultan antara regresi dan korelasi ternyata Gaji dan Insentif berpengaruh positif dan signifikan terhadap prestasi kerja karyawan. Hal ini dapatlah disajikan hasil pembahsan dalam peneltian ini yaitu sebagai berikut :

1. Pengaruh Gaji dan Insentif dengan Prestasi Kerja Karyawan melalui pegujian regresi, ternyata ada pengaruh yang positif anatar Gaji dan Insentif dan Presatsi kerja karyawan. Hal ini menunjukkan bahwa pemberian gaji dan insnetif pada gedung wanita rajawali palembang berdampak terhadap prestasi kerja karyawan akan dapat lebih ditingkatkan.

2. Hasil uji parsial yang sebagaimana telah dilakukan ternaya ada penagruh yang signifikan antara gaji dan insentif terhadap prestasi kerja karyawan.

Dimana peningkatan gaji dan insentif karyawan dapat diikuti oleh peningkatan prestasi kerja karyawan.

Kemudian dari hasil uji hipotesis yang sebagaimana telah dilakukan ada pengaruh yang signifikan antara gaji dan insentif terhadap prestasi kerja karyawan. Dengan demikian hipotesis pertama yang diajukan dapatlah dikatakan terbukti.

\section{KESIMPULAN DAN SARAN}

\subsection{Kesimpulan}

Berdasarkan hasil analisis dan pembahasan yang telah dikemukakan sebelumnya, maka akan disajikan kesimpulkan sebagai berikut :

. Pengaruh anatara gaji dan insentif dengan prestasi kerja karyawan khusunya pada gedung wanita rajawali palembang, ternyata diketahui ada pengaruh yang positif dan signifikan antara gaji dan insentif terhadap prestasi kerja karyawan. Dengan demikian hipotesisnya terbukti.

\subsection{Saran-saran}

Sebagai bahan pertimbangan bagi pihak perusahaan yang berdasarkan hasil analisis dan kesimpulan diatas, maka disarankan agar :

1. Perlunya Perusahaan meningkatkan prestasi kerja karyawan diantaranya meningkatkan pemberian gaji dan insentif. Hal ini akan dilakukan untuk dapat meningkatkan prestasi kerja.

2. Sebaiknya mulai melakukan analisa atas tiap-tiap karyawan dari berbagai level dan lakukanlah identifikasi akan hal-hal yang dapat meningkatkan prestasi kerja karyawan. Peningkatan prestasi kerja karyawan akan berbanding lurus dengan peningkatan keberhasilan perusahaan yang tentunya akan diikuti juga dengan peningkatan penghasilan perusahaan 


\section{DAFTAR PUSTAKA}

Astrid Tanjung Sari, Pemberian kompensasi berpengaruh positif, pada kinerja karyaawan(2008)

Departemen Pendidikan dan Kebudayaan. Kamus Besar Bahasa Indonesia,Edisi 3. Balai Pustaka Jakarta. 2011

Dharma, Agus. Manajemen Prestasi Kerja. Edisi Pertama Rajawali, Jakarta. 2012

Gibson, James L., Ivancevich, Donnelly, Jr, Organisasi: Perilaku, Struktur, Proses. Edisi I. Bina Rupa Aksara, Jakarta. 2010

Hamalik, Oemar. Psychologi Manajemen. Tri Gendakarya, Bandung.2010

Handoko, Hani. Manajemen Personalia. BPFE, Yogyakarta.2011

Hariandja, Marihot, T.E. Manajemen Sumber Daya Manusia, Grasindo. Jakarta.2012

Mangkunegara, A. Prabu. Evaluasi Kinerja SDM, Refika Aditama, Bandung.2012

Mangunhardjana, A.M. Mengembangkan Kreativitas, Terjemahan dari David Cambell. Kanisius, Jakarta.2010

Malayu S.P Hasibuan, Manajemen Sumber Daya Manusai, Grasindo, Jakarta, 2011

Nitisemito, . Evaluasi Kinerja SDM, Refika Aditama, Bandung.2011

Pasal 1 angka 30 Undang-Undang Nomor 13 Tahun 2003 tentang Ketenagakerjaan).

Robbins, Stephen. P.. Perilaku Organisasi: Konsep, Kontroversi, Aplikasi. Alih bahasa: Hadyana. Preinhallindo, Jakarta. 2013

Sri Wuryanti, Pengaruh Kompensasi dan Lingkungan kerja TerhdapPrestasi Kerja Dengan Motivasi Sebagai Mediasi Jakarta 2008

Warsidi ,Kompensasi berpengaruh positif dan signifikan terhadap kinerja guru; kepuasan kerja berpengaruh positifdan signifikan terhadap kinerja guru (2004).

Semiawan, Conny,. Memupuk Bakat dan Kreativitas Siswa Sekolah Menengah. Gramedia Jakarta.2012

Simamora,Manajemen Sumber Daya Manusia, Grasindo. Jakarta.2010

Zaeni Asyhadie Manajemen Sumber Daya Manusia, Gramedia ,Jakarta 2011 